\title{
Recognizing Women's Rights at Work: Health and Women Workers in Global Supply Chains
}

\author{
Erika R. George* \\ Candace D. Gibson** \\ Rebecca Sewall*** \\ David Wofford $* * * *$
}

\section{TABLE OF CONTENTS}

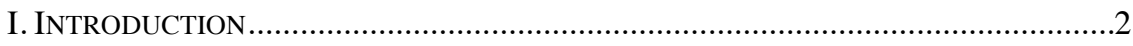

II. GLOBALIZATION, WOMEN's HEALTH, AND WOMEN WORKERS IN

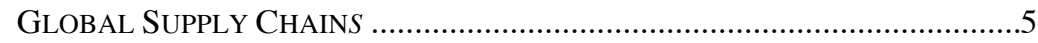

A. Women's Health in Globalized Communities.....................................6

B. Women's Health, Reproductive Health, and the Workplace in the Global Economy ......................................................................

C. Occupational Safety and Health Conventions and the Health Concerns of Women Workers ..........................................................13

III. THE RIGHT TO HEALTH ...........................................................................18

A. The Right to Health in International Human Rights Law ...............21

1. The International Covenant on Economic, Social, and

DOI: https://dx.doi.org/10.15779/Z381R6N059

* Professor Erika R George, Professor of Law, University of Utah S.J. Quinney College of Law, B.A., University of Chicago; M.A. University of Chicago; J.D., Harvard Law School. The authors would like to acknowledge Stina Peterson for her excellent research assistance.

** Candace D. Gibson, Policy Counsel at National Latina Institute for Reproductive Health. Candace received her J.D. from University of Utah S.J Quinney College of Law.

*** Rebecca Sewall, PhD., gender expert and former principal at ThinkBIG (Balanced and Inclusive Growth).

**** David Wofford, Senior Advisor for Workplace Policies, Evidence Project and Vice President, Meridian Group International, Inc. The contribution to this article by Wofford, Gibson and Sewall was made possible through the Evidence Project and the support of the United States Agency for International Development (USAID) under the terms of cooperative agreement no. AID-OAA-A-1300087. The contents of this document do not necessarily reflect the views of USAID or the United States Government. 
Cultural Rights ("ICESCR")

2. The Availability, Accessibility, Acceptability, and Quality (AAAQ) Framework

3. The Convention on the Elimination of All Forms of Discrimination against Women ("CEDAW")....

4. Other Treaties That Support a Right to Health and Sexual and Reproductive Health .28

5. The Right to Health in International Policy .29

B. Other International Declarations, Frameworks, and Initiatives on Workplace Health

\section{The UN GUIDING PRINCIPLES, CORPORATE Due DiLigenCE \&}

WORKPLACE HEALTH

V. BUSINESS BENEFITS, HEALTH RIGHTS \& RECOMMENDATIONS ..........................41

VI. CONCLUSION

Our working conditions are horrible. We basically never get a day off. . I was ill as well. But I had no choice but to go to work, because they had threatened not to pay me if I didn't.

\section{(Mushamat Sokina Begum, Survivor, Rana Plaza Bangladesh) ${ }^{1}$}

The improvement of girls' and women's health becomes not only a moral, but also an economic imperative because healthy workers have more energy, improved mental health, and are less likely to be absent from work than unhealthy ones.

(The Lancet Commission on Women, Health and Sustainable Development $)^{2}$

I.

\section{INTRODUCTION}

Across the world, millions of women in developing countries are working in global supply chains to produce the foods we eat and the products we use. Women workers in developing countries are primarily concentrated in agribusiness ${ }^{3}$ and in certain manufacturing sectors. ${ }^{4}$ Women working in global

1. Hasnain Kazim (Ella Ornstein, trans.), Bangladesh Seamstress: 'I Had No Choice but to Go to Work', SPIEGEL ONLINE INT'L (May 16, 2013), http://www.spiegel.de/international/world/bangladesh-factory-worker-discusses-horrible-workingconditions-a-899976.html.

2. Ana Langer et al., Women and Health: The Key for Sustainable Development, 386 THE LANCET 1165, 1169 (2015), http://dx.doi.org/10.1016/S0140-6736(15)60497-4.

3. The authors define agribusiness as large-scale business operations involved in farming, seed supply, agrichemicals, farm machinery, processing, and manufacturing and/or the packaging and distribution of products.

4. ILO, Global Employment Trends FOR WOMEN 28 (2012), 
supply chains have new opportunities to earn more money in the formal economy and to enjoy more autonomy than ever before. Yet, while women enjoy greater autonomy as they earn more money, they still encounter challenges including low wages relative to the wages of men, life in dormitories, and pressure to send remittances home. Often women who migrate for work are disconnected from their families and from the other private and public support systems where they live. The pressure to meet production schedules, the poor quality of most workplace nurses and doctors, the limited availability of affordable health care, and the ignorance of managers of the particular needs of women workers all conspire to harm the health of women workers.

Women workers in global supply chains in many poor countries have little or no access to quality health care. The health needs of these women workers are significantly different from those of men. The general health and well-being of women can be harmed by work conditions through restrictive policies and practices that fail to recognize the unique needs of women workers. The relationship between health and work permeates all aspects of a worker's daily life and does not cease when the workday ends. This is especially true for women who may also have domestic duties as care givers. A broader assessment of the systemic risks to women workers' general health and the potential violations of their health rights is essential and too often has been overlooked.

Much attention has been paid to important, acute violations of sexual harassment and violence, as well as exposure to chemicals. The less acute, but no less important, long-term harms to women from the lack of access to general and reproductive health services and products, the poor quality of workplace infirmaries and practices of workplace health providers, and the poor sanitary conditions at work have received inadequate attention. These harms and potential rights violations remain unrecognized because occupational health and safety standards and public health standards have not been aligned. The largely gender-blind approach of Occupational Safety and Health (OSH) strategies hides from the world the negative impact of particular workplace policies and practices on women's health. Business policies and practices regulating global supply chains have yet to take women's health seriously as both a human rights concern and a fundamental business interest. The failure to align OSH and public health standards with international human rights standards leaves businesses open to the risk of complicity in creating or supporting conditions that may cost women workers their health and livelihoods.

http://www.ilo.org/wcmsp5/groups/public/--dgreports/--

dcomm/documents/publication/wcms_195447.pdf (noting that globally, in 2012, over a third of women were employed in agriculture, almost half in services, and a sixth in industry, with a quarter of women in East Asia employed in industry); OXFAM INT'L, TRADING AWAY OUR RIGHTS: WOMEN $\begin{array}{llllll}\text { WORKING IN } & \text { GLOBAL } & \text { SUPPLY } & \text { CHAINS } & 16 & \text { (2004), }\end{array}$ https://www.oxfam.org/sites/www.oxfam.org/files/rights.pdf (noting that due to trade liberalization, women workers occupied sixty to ninety percent of labor intensive jobs in clothing and fresh produce global supply chains in 2004). 
As the global economy has changed dramatically over the last thirty years and with it the gender composition of the workforce, it is time to rethink the occupational safety and health standards that have served as the lens through which companies uphold the health rights and safety of workers. Women workers, and men as well, have been harmed by a long-standing divide between health rights in the workplace as defined by OSH standards and health rights as defined by international human rights law. While the protection of human rights is primarily a government responsibility, there is growing interest in ensuring that private sector companies also abide by internationally recognized human and labor rights. The United Nations Guiding Principles on Business and Human Rights ("Guiding Principles" or "UNGPs") recognize the responsibility of companies to "respect" human rights in their operations. ${ }^{5}$

The Guiding Principles offer an opportunity to call into question old assumptions that health rights at the workplace should be defined primarily by OSH standards as separate from the general right to health under international law. Additionally, new non-legally binding frameworks promote the idea that states and corporations should take a more comprehensive view of the health needs of workers including sexual and reproductive health, occupational health and safety, workplace health services, and the general well-being of workers. These new frameworks include a growing number of voluntary principles, corporate codes of conduct, and certification and reporting schemes that are designed to prevent companies from inflicting harm on workers and citizens or infringing their human rights. These new mechanisms rely on market forces, corporate commitments, and public shaming instead of legal institutions for enforcement. The Guiding Principles and a range of other new non-legal or quasi-legal mechanisms that some may consider to be outside the realm of the rights system or beyond the scope of corporate social responsibility could allow for a more robust re-envisioning of the ability of the business community to influence the right to health in the workplace. These new standards and strategies may hold the potential to provide an avenue for advancing reproductive health rights in the workplace and beyond.

The Guiding Principles mandate that businesses respect the human rights enshrined in the International Bill of Human Rights and in the International Labour Organization (ILO)'s Declaration on Fundamental Principles and Rights at Work. Due diligence processes and risk impact assessments are the main recommended means for ensuring compliance with companies' commitments to respect international human rights. Because OSH as a conceptual framework and regulatory order is not sufficient to identify the risk of health rights violations to women workers, we argue companies should not anchor their due diligence and risk assessment in OSH conventions and settle for a check-the-box

5. Special Rep. of the Secretary-General on the issue of human rights and transnational corporations and other business enterprises, Guiding Principles on Business and Human Rights: Implementing the United Nations "Protect, Respect, and Remedy" Framework, I 1, U.N. Doc. A/HRC/17/31 (Mar. 21, 2011) (by John Ruggie) [hereinafter Guiding Principles]. 
solution where worker health is at risk. Rather, a more robust appreciation of the substantive content of the human right to health on the part of business enterprises could result in better health outcomes for all workers and reduce the risk of rights abuses in the workplace. We re-examine the right to health of women workers and explore the reasons for aligning OSH with human rights health standards relevant to global business enterprises.

We use a gender lens to bring the lack of alignment between standard approaches to occupational safety and health and international human rights standards into sharper focus. ${ }^{6}$ Looking through a gender lens we find a more consistent, and ultimately more business-friendly, approach to improving the health of women workers - and, thereby, all workers could benefit from aligning OSH policy priorities with new principles designed to incorporate respect for human rights into business practices. In Part II, we give an overview of the impact of globalization on the health of women workers and outline the current application of occupational health standards. In Part III, we analyze the right to health for women under international law as well as the non-human rights mechanisms that inform the role of the workplace in ensuring worker health. In Part IV, we review the Guiding Principles with particular attention devoted to the due diligence responsibilities of corporations as relevant to the health of women workers. Finally, we conclude with a preliminary set of recommendations for aligning OSH with general health rights to inform the development of due diligence and human rights impact assessment processes consistent with the UNGPs.

II.

\section{GLOBALIZATION, WOMEN'S HEALTH, AND WOMEN WORKERS IN GLOBAL SUPPLY CHAINS}

Globalization and the development of market economies in poor and low income countries have had significant and in large part positive impacts on women, including on their gender roles and employment opportunities. Growth in many emerging market economies is characterized by global supply chains made up of national-level producers providing goods internationally. In the international system, transnational retailers and brands possess significant power to directly and indirectly influence labor conditions in their supply chains. ${ }^{7}$

6. The authors use the term gender lens to describe an analytical approach that identifies and describes the differential impact on women and men of norms, policies and practices in society and in the workplace. We use a gender lens in this Article to understand the unique challenges women face in pursuing their health rights and the ways systems, institutions, and polices must change to achieve women's equality. See Using a Social Change Lens to Advance Gender Equality, WOMEN's FOUND. OF MINN., http://www.wfmn.org/PDFs/WFM_AdvancingEqualityLogicModelTraining.pdf (last visited Mar. 4, 2016).

7. Tiana O'Konek, Corporations and Human Rights Law: The Emerging Consensus and its Effects on Women's Employment Rights, 17 CARDOZO J.L. \& GENDER 261, 265 (2011). 
A growing number of poor women are joining the workforces in countries that export produce and products manufactured for global consumption. In some industries, such as apparel, women comprise a majority of the workforce, sometimes as much as $80 \%$ or more in the garment industry. ${ }^{8}$ Many of the women entering the workforce are undereducated. ${ }^{9}$ Women often migrate from their homes in rural areas to cities, not to mention other countries, because they want and need work. ${ }^{10}$ An estimated 105 million workers leave their homes to find work in other countries, including in the supply chains of international corporations. ${ }^{11}$ Nearly $50 \%$ of those leaving their countries are women who claim their primary motivation for migrating is employment. ${ }^{12}$ The number of internal migrants is equally significant. ${ }^{13}$

Migration and the changing composition of the workforce are driven in part by the active efforts of factories and industrial farms to recruit workers. Manufacturers and agribusiness are drivers in efforts to actively recruit these women - and men - to leave their homes to work in enterprises that produce the goods they supply to the global export economy. ${ }^{14}$

\section{A. Women's Health in Globalized Communities}

Globalization and related changes, such as urbanization, have brought benefits for women including shifting gender norms and granting working women greater autonomy over their lives. ${ }^{15}$ Globalization has contributed to reduced gender inequality through increasing the likelihood that a girl will get

8. ILO, Progress AND POtential: How BetTer WORK IS IMPROVING Garment WORKERS' LIVES AND BOOSTING FACTORY COMPETITIVENESS 11 (2016), http://betterwork.org/dev/wp-content/uploads/2016/09/BW-Progress-and-Potential_Web-final.pdf; see also Peder Michael Pruzan-Jorgensen, Business Must Close the Gender Gap, BSR BLOG (Mar. 7, 2016), www.bsr.org/en/our-insights/blog-view/business-must-close-the-gender-gap.

9. OXFAM INT'L, supra note 4, at 18.

10. Eva Dienel, The Future of Women's Empowerment in Global Supply Chains, BSR BLOG (Mar. 6, 2014), http://www.bsr.org/en/our-insights/blog-view/the-future-of-womens-empowermentin-global-supply-chains.

11. InT'L ORg. FOR Migration, Migration Initiatives 2014: Health OF Migrants (2013), http://publications.iom.int/bookstore/free/Migration_Initiatives2014_web.pdf.

12. ILO, PROMOting DeCENT WORK FOR Migrant WORKers 1 (2015), http://www.ilo.org/wcmsp5/groups/public/--ed_protect/--protrav/-migrant/documents/publication/wcms_344703.pdf.

13. U.N. Dep'T of ECON. \& CUltural AfFairs (Population Div.), TeChNical Paper

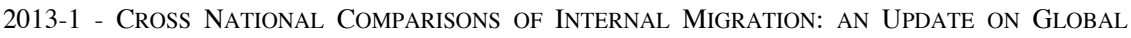
PATTERNS AND TRENDS (2013).

14. Labor Migration in China and Mongolia, ILO, http://www.ilo.org/beijing/areas-ofwork/labour-migration/lang-en/index.htm (last visited Mar. 4, 2016).

15. World Bank, Globalization's Impact on Gender Equality: What's Happened and What's Needed, WORLD DEVELOPMENT REPORT 2012: GENDER EQUALITY 254, 267-68 (2012). 
an education. ${ }^{16}$ Globalization has also been credited with aiding greater availability of health and social services for women and girls. ${ }^{17}$

Despite generating gains in gender equality, however, globalization's benefits and burdens have not been equitably balanced. For example, a 2015 Lancet Commission report on Women and Health notes: "Globalisation generates new challenges, its benefits have not been uniformly distributed, and effects on women have been mixed. Globalisation has increased inequality between and within countries, polarized societies by income and economic status, and accelerated disease migration-including widespread adoption of an unhealthy lifestyle and diet-contributing to the increase in NCDs [noncommunicable diseases] and women's changing disease burden." 18 This is particularly true for women workers, who are paid less than men and have less job security, often without union representation. ${ }^{19}$ Indeed, "[w]omen's participation in the labour market, while continuing to undertake most domestic work and care giving, is a potential burden and threat to women's health and well-being; little time is left for rest and leisure, resulting in a double burden of work," the Lancet Commission reported. ${ }^{20}$

It is common to assume that poor women living in urban areas, especially with formal employment, are better off than those in rural areas. While true as a generalization, this assumption masks wide disparities based on social status and wealth. For example, a 2010 study of thirty countries found significant inequalities in access to health care and maternal health services. Poor women in urban settings were not necessarily better off than rural women even though they lived closer to health services. ${ }^{21}$ Furthermore, urban women were found to have no better level of reproductive health than rural women..$^{22}$ There is also evidence that a significant disparity in the quality of services available to the poor and the better off exists in many cities. A 2009 study conducted in Delhi, India, found that close proximity of the poor to formal health care providers was of little value: "The quality of care available in the poor neighborhoods proved to be so low that the authors could fairly describe it as "money for nothing.",23

The lack of access to quality health services, clean water, or sanitation is compounded for the urban poor who live in crowded homes and have increased

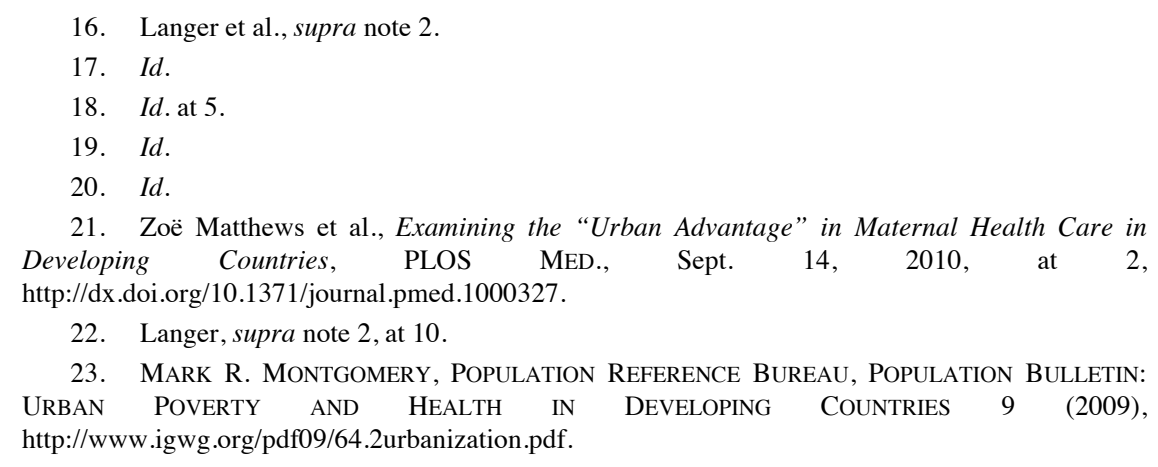


risk of disease from water, air, and food ${ }^{24}$ For women, these factors are further compounded by concerns for physical safety, gender norms that reduce their level of exercise, and an urban lifestyle that changes what they eat, all of which can lead to chronic illness and non-communicable diseases. ${ }^{25}$ Poor women are especially vulnerable, because lower social status and gender discrimination increase their risk of unwanted or risky sex and violence, as well as their likelihood of living in bad housing conditions. ${ }^{26}$ Poor women also have less autonomy to make reproductive decisions or to access the services they need, even when services are available. ${ }^{27}$

The pervasive reality in low and middle income countries for many women is poor access to services and poor quality of care..$^{28}$ The care they do receive is typically from female health providers, the most disenfranchised people in health systems, who are, in turn, under-supported and under-valued and thus unable to reach their potential. ${ }^{29}$ In an increasingly female global workforce, the Lancet Commission lamented: "Few gender-sensitive policies exist that enable women to integrate their social, biological, and occupational roles, function to their full capacity, and realise their fundamental human rights." 30

\section{B. Women's Health, Reproductive Health, and the Workplace in the Global Economy}

Employers have a significant, often negative, impact on the health and well-being of their women workers as management fails to recognize the unique needs of women. While the protection of public health remains a challenge for many countries, the poor health practices and policies in many workplaces can exacerbate this situation. Recently, public health and the international development community have aligned through the new Sustainable Development Goals (SDGs). ${ }^{31}$ The SDGs have called for government and business commitments to improve the health and well-being of women and girls ${ }^{32}$ and increase access to family planning. ${ }^{33}$ The occupational health

24. Id. at 6 .

25. Langer, supra note 2 , at 6 .

26. Id. at 9 .

27. Id.

28. Id.

29. Id. at $19-20$.

30. Id. at 11 .

31. G.A. Res. 70/1, U.N. Doc. A/RES/70/1 (Sept. 25, 2015).

32. See Jessica Davis Pluess \& Peder Michael Pruzan-Jorgensen, Women's Empowerment in Global Value Chains: Framework for Business Action (Women Deliver Private Sector PreConference, Working Paper, 2016), https://www.bsr.org/reports/BSR_WomenDeliver_Womens_Empowerment_Value_Chains_Consult ation_Draft.pdf.

33. Ellen Starbird et al., Investing in Family Planning: Key to Achieving the Sustainable Development Goals, 4(2) Global HeAlth: SCI. \& PRAC. 191, 191 (2006). 
community approach has yet to fully align with these efforts. ${ }^{34}$ Moreover, the management of business enterprises employing low-wage women workers, the multinational buyers they supply to, and the oversight agencies for workplaces have generally shown little recognition of the fact that companies could have any responsibility for the general or reproductive health of women workers, or that health beyond the narrow legal compliance to occupational safety is relevant to current $\mathrm{OSH}$ regulation. ${ }^{35}$

Current policies and priorities reflect only a subset of women workers' health concerns, such as sexual harassment and gender based violence, chemical exposures that affect reproductive health, pre-employment pregnancy testing, and lack of maternity leave. ${ }^{36}$ It is not common for observers interested in occupational concerns to focus on how poor policies and practices affect a woman worker's health day in and day out, their access to health services, or the quality of health services they receive onsite or off, which are central to a person's right to health.

Restrictive workplace policies can have disparate impacts on women and men. For instance, it is well documented that the lack of hydration and restroom breaks increase the risk of urinary tract infections for women. ${ }^{37}$ And without access to operating toilets, restrooms with soap and water, ${ }^{38}$ and sanitary napkins, women workers are forced to use unsanitary products, sometimes scraps from a factory's own waste, which can cause gynecological infections. ${ }^{39}$ Gynecological infections are not typically considered "occupational diseases" and they do not affect men-the typical worker when OSH standards were first developed.$^{40}$ Restrictive policies, inadequate facilities, and even intimidation by

34. Daniel Malan et al., Vitality, Reporting on Health: A Roadmap FOR INVESTORS, COMPANIES AND REPORTING PLATFORMS 15 (2016), http://thevitalityinstitute.org/site/wpcontent/uploads/2016/01/Vitality-HealthMetricsReportingRoadmap22Jan2016.pdf.

35. Id. at 39 .

36. BUS. FOR SOC. RESPONSIBILITY (BSR), HEALTHCARE DELIVERY IN RMG FACTORIES IN BANGLADESH: What ARE THE MisSED OPPORTUNITIES? 1 (2014), http://www.bsr.org/reports/BSR_Healthcare_Delivery_in_RMG_Factories_in_Bangladesh.pdf; see also WAR ON WANT, STITCHED UP: WOMEN WORKERS IN BANGLADESHI GARMENT SECTOR 1 (2011), http://www.waronwant.org/sites/default/files/Stitched\%20Up.pdf (describing the violations that Bangladeshi women experience in the garment industry).

37. OXFAM INT'L, supra note 4, at 60; see also OXFAM INT'L, BETTER JOBS IN BETTER SuPPLY CHAINS 11 (2010), https://www.oxfam.org/sites/www.oxfam.org/files/b4b-better-jobsbetter-supply-chains.pdf.

38. ILO, supra note 4 at 60; ILO \& BETTER FACTORIES CAMBODIA, THIRTY FIRST SYNTHESIS REPORT ON WORKING CONDITIONS IN CAMBODIA'S GARMENT SECTOR 5, 7 (2014).

39. Water Aid, UnileVer \& Water Supply SANitation Collaborative Council, We CAN'T WAIT: A REPORT ON SANITATION AND HYGIENE FOR WOMEN AND GiRlS 7 (2013), https://www.unilever.com/Images/slp-wateraid-women-girls-nov-2013_tcm244-417254_1.pdf (reporting that in one factory case study in Bangladesh, $60 \%$ of workers used rags from the factory floor as menstrual cloths, resulting in infections and absenteeism).

40. ILO, ILO LIST OF OCCUPATIONAL DISEASES (2010), http://www.ilo.org/wcmsp5/groups/public/@ed_protect/@protrav/@safework/documents/publicatio n/wcms_125137.pdf. 
employers can contribute to harmful health conditions that are unique to women workers. Managers in many workplaces are predominantly male ${ }^{41}$ and do not typically consider menstruation a workplace concern, if they care to think about it at all. A woman worker must think about menstruation-her ability to manage pain, access products and the ability to have some privacy affects her health, wellbeing, and productivity. When an employer requires a time card to clock restroom breaks ${ }^{42}$ or yells at workers to staff at their work stations, ${ }^{43}$ the employer sends a clear and intimidating signal to women workers about workplace priorities and the degree of concern for women's health needs.

Access to health services is a major problem for poor women in general, but for women workers the barriers are even higher not only because of their double burden of domestic and paid work, but also because of the hours and days they work. Most public health facilities are closed after normal work hours and on weekends, which means that women workers have access to a limited number of private health providers. ${ }^{44}$ In workplaces with onsite infirmaries and related health programs, worker access may not be much better. When there is a sign on an infirmary wall saying "No entry without permission," which one of the authors witnessed, the message to workers about the availability of services and importance of their health is also very clear. ${ }^{45}$

Even in workplaces where there are good policies meant to ensure a worker's agency to leave her post to receive health services on or offsite, middle management practices often undermine these policies. The reason is straightforward: workplaces operating in global supply chains must meet constantly changing and urgent production demands and deadlines. Many labor advocates have documented how production demands on factories and farms come at the expense of labor and human rights and voluntary codes of conduct endorsed by corporate buyers, ${ }^{46}$ but they also come at the expense of health rights. A woman worker who was selected for a health education program one of the authors participated in was told by her line supervisor that if she attended a training session that day she would be fired. He needed to meet a deadline. ${ }^{47}$

41. O'Konek, supra note 7, at 265.

42. Central News Agency, Factory Restricts Employees' Bathroom Use to Twice A Day, EPOCH TiMES, May 28, 2007, http://www.theepochtimes.com/n3/1732566-factory-restrictsemployees-bathroom-use-to-twice-a-day.

43. Human Rights Watch, "Work Faster or Get OUT": LABOR RightS AbuSES iN $\begin{array}{lllll}\text { CAMBODIA'S GARMENT } & \text { INDUSTRY } & 7 & \text { (2016), }\end{array}$ https://www.hrw.org/sites/default/files/reports/cambodia0315_brochure_web.pdf.

44. UNFPA (Asia PaC. Reg'L Office), Socio-Cultural Influences ON The $\begin{array}{llllll}\text { REPRODUCTIVE HEALTH } & \text { OF } & \text { Migrant } & \text { (2011), }\end{array}$ https://www.unfpa.org/sites/default/files/pub-pdf/Migrant_Regional.pdf.

45. David Wofford, Field observation at garment factory, Cambodia (Nov. 19, 2014) (unpublished report) (on file with author and Evidence Project/Meridian Group International, Inc.).

46. O'Konek, supra note 7, at 264-65.

47. This is if the workplace employs a certain number of workers, typically more than 300 workers. Project implementation team field report and oral report to David Wofford on training activities, Garment Factory, Egypt, (Nov. 22, 2009) (unpublished report) (on file with author). 
While this may not rise to the level of what is conventionally understood to be a gross human rights violation, it underscores the power imbalance between women workers who seek protections or assert their rights and supervisors who can undermine programs sanctioned by their senior management. Too often a woman is only able to exercise her rights and leave her station to get health care in the case of an emergency or very serious health problem. Minor health problems persist, hampering productivity, until they become serious enough to require action costing the worker lost pay, lost work, more expensive care, and potentially longer term adverse health impacts. ${ }^{48}$ The policies and practices of the employer directly affect whether or not women workers can access needed health care.

Workplaces can also affect the quality of care that women workers receive. First, when employers restrict, by policy or practice, the freedom of workers to access health services during working hours, this reduces the choices women workers have for quality services after hours and on weekends. Second, while many countries require larger formal workplaces to employ health care workers and provide space for a health infirmary, ${ }^{49}$ the quality of these health providers, who are typically under-paid and under-trained nurses, tends to be very low. Many do not even have diplomas. A study of nurses in Bangladesh garment factories found "a discernible mismatch between the training received by the nurses and the actual health needs in ready-made garment (RMG) factories."50 They had limited training on basic diagnosis, counseling or patient education, treatment, and referral, all of which are roles they must play. The nurses did not provide information on personal hygiene, waterborne diseases, or sexually transmitted diseases, and they lacked relevant knowledge of issues important to workers, such as sexual and reproductive health. Yet $70 \%$ of the nurses said that menstrual pain was one of the top complaints they hear from workers. ${ }^{51}$ Factories hired nurses to meet compliance requirements and paid them less than in private facilities, the study noted, "but they are not legally incentivized to hire a qualified nurse or to invest in his or her professional development once hired." 52 Far from being the worst examples, the factories in this study were among those most committed to worker health in company goals and operations. As with workplaces everywhere, focused on occupational compliance rather than health rights, managers have no awareness of how their practices and poor standards are contributing to women workers' health.

Many workplaces have infirmaries and health care providers that do not meet common public health standards for cleanliness, confidentiality, privacy, health information, and referral. Assessment by outside health groups regularly find poor or hazardous practices, from inconsistent handwashing and poor

\footnotetext{
48. HUMAN RIGHTS WATCH, supra note 43, at 3, 7-9.

49. See, e.g., Bangladesh Labour Act of 2006, Chapter 8, Welfare Measures, number 89 (5).

50. BSR, supra note 36 , at 9.

51. Id. at 10

52. Id. at 9 .
} 
record-keeping to disposure of needles and bloody materials in unsafe containers. ${ }^{53}$ Since these are not primary care facilities, much of what they do is refer patients to care. But nurses are too often unprepared to make effective referrals, as they do not know who the quality providers in the community are or where to refer women workers for their specific needs. ${ }^{54}$ Referrals from a workplace infirmary may well reinforce norms for poor women receiving low quality services.

One of the services women workers, who are usually in prime reproductive years, need most and yet are least likely to request is reproductive health and family planning. This issue may seem far removed from the employers' obligation under occupational safety and health requirements: employers' main concern about reproductive health is a pregnant worker-and avoiding obligations ${ }^{55}$ It is common for workers to be denied sick leave while pregnant and to have barriers to their access to ante-natal or post-natal-care ${ }^{56}$ Women workers who choose to complete their pregnancies are too often denied maternity leave, even if it is required under a State's law. ${ }^{57}$ Yet the corporate role in recruiting workers, housing them, and transporting them-as well as the business interest in helping these needs get met-requires a more comprehensive view about employers' obligations to women's reproductive health. Female migrant workers, like many displaced populations, are more likely than the general population to encounter sexual contact-both wanted and unwanted-when placed in a new unfamiliar environment. ${ }^{58}$ Young women workers lack basic knowledge in reproductive health and their employers assume that these workers will not engage in sexual activity prior to marriage, creating an additional barrier to care, services, and information. ${ }^{59}$ Employers may contribute to these workers' health risks, and not just occupational health risks, by limiting access to quality services onsite and off, hiring workplace health providers with limited knowledge of the health needs of women workers, failing to provide health education information in their clinics, and exacerbating these poor conditions with production demands at the workplace.

53. Carolyn Rodehau \& David Wofford, The Evidence Project, Brief: STRENGTHENING FACTORY HEALTH SySTEMS UNDER LEVI STRAuSS \& CO.'S WORKER WellBEING INITIATIVE IN EGYPT 4 (2015), http://evidenceproject.popcouncil.org/wpcontent/uploads/2016/03/Levis-Brief_3.22.16.pdf.

54. BSR, supra note 36 , at 9 .

55. HUMAN RightS WATCH, supra note 43 , at 67.

56. WAR ON WANT, supra note 36 , at 8 .

57. Id. at 9 .

58. M. Puri \& J. Cleland, Sexual Behavior and Perceived Risk of HIV/AIDS Among Young Migrant Factory Workers in Nepal, 38 J. ADOLESCENT HEALTH 237 (2006).

59. BSR, Women's General and ReProductive Health in Global Supply Chains 6 (2006), https://herproject.org/downloads/BSR-Womens-Health-Report-2006.pdf. 


\section{Occupational Safety and Health Conventions and the Health Concerns of Women Workers}

Occupational Health and Safety standards are based on a set of conventions, protocols, and recommendations adopted by the International Labor Organization (ILO) and ratified by Member States. Each national government sets its own laws and specific regulations governing employers and workplace safety, but these have been developed in reference and in relation to ILO standards. For a range of historical reasons, ILO standards do not fully or adequately address the right to health for women workers, even as the OSH community has tried to address the needs of a changing global workforce that increasingly includes women.

Since its inception in 1919, the ILO has been concerned with worker safety and health harms related to work. Formed as part of the Treaty of Versailles that ended World War I, its creation was driven by the belief that social injustice at the workplace could threaten the peace that was achieved. ${ }^{60}$ It is the only tripartite United Nations organization that is represented by "governments, employers and workers of 187 member States to set labour standards, develop policies and devise programs promoting decent work for all women and men." 61 In its first two decades, it introduced ground-breaking protections for workers' health in the areas of maternity protection, lead paint, building safety, and accidents affecting dockers. ${ }^{62}$ Later conventions in the 1980 s represented major steps forward in workers' health rights. ${ }^{63}$

Since 1919, worker health and safety has been a continuing concern of the ILO with more than 40 conventions and recommendations addressing OSH issues. ${ }^{64}$ Occupational safety has been an area of significant success for the ILO. ${ }^{65}$ In the later conventions and the Promotional Framework for Occupational Safety and Health Convention from 2006, health is

60. Origins and History, ILO, http://www.ilo.org/global/about-the-ilo/history/langen/index.htm (last visited Oct. 25, 2016).

61. About the ILO, ILO, http://ilo.org/global/about-the-ilo/lang-en/index.htm (last visited Oct. 25, 2016).

62. Ilo, ilo Maternity Protection (Agriculture) ReCOMmendation (No. 12): RECOMMENDATION CONCERNING THE PROTECTION, BEFORE AND AFTER CHILDBIRTH, OF WOMEN WAGE-EARNERS IN AGRICULTURE (1921) (withdrawn), http://www.ilo.org/dyn/normlex/en/f?p=NORMLEXPUB:12100:0::NO:12100:P12100_ILO_CODE: R012. Current maternity protections are guaranteed by three ILO Conventions: Revision of the Maternity Protection Convention (No. 183), June 15, 2000, 2181 U.N.T.S. 253; Safety Provisions in the Building Industry (No. 637), June 23, 1937, 40 U.N.T.S. 233; Protection against Accidents of Workers Employed in Loading or Unloading Ships (No. 611), Apr. 27, 1932, 39 U.N.T.S. 103.

63. In the 1980s, the ILO adopted the Occupational Safety and Health Convention and the Occupational Health Services Convention. Occupational Health Services Convention (No. 161), June 26, 1985, 2 I.L.C.R. 1334; Occupational Safety and Health Convention (No. 155), June 22, 1981, 1331 U.N.T.S. 279.

64. Malan, supra note 34 , at 15.

65. See Alan Hyde, The International Labor Organization in the Stag Hunt for Global Labor Rights, 3 LAW \& ETHICS HUM. RTS. 153 (2009). 
conceptualized, as one would expect, from a labor perspective and as only related to the workplace. The ILO's Occupational Safety and Health Convention No. 155 ("Safety and Health Convention") defines health in relation to work as "indicat[ing] not merely the absence of disease or infirmity [but] also ... the physical and mental elements affecting health which are directly related to safety and hygiene at work." 66 According to the ILO, the aim of national policy of States ratifying the Safety and Health Convention is to "prevent accidents and injury to health arising out of, linked with or occurring in the course of work, by minimising, so far as is reasonably practicable, the causes of hazards inherent in the working environment." ${ }^{67}$ In other words, States are responsible for enforcing employer compliance with regulations that protect against employment-related risks that might be experienced in the workplace by virtue of one's status as worker. This conceptualization of health at the workplace does not include protecting health-related rights that workers have by virtue of the fact that they are human beings, which is the basis of all human health rights. ${ }^{68}$

Under the ILO, the right to occupational health and safety is a not a core labor standard. ${ }^{69}$ In 1998, in response to concerns about how the ILO should respond to globalization and international trade regimes, the ILO adopted the Declaration on Fundamental Principles and Rights at Work, which defined a set of "core labor standards" and non-core substantive standards ${ }^{70}$ and made gender equity a cross-cutting issue of its Decent Work agenda. ${ }^{71}$ The declaration has been subject to much critique and debate beyond the scope of this paper, including whether this declaration undermined the importance of socioeconomic

66. Occupational Safety and Health Convention (No. 155) art. 3(e), June 22, 1981, 1331 U.N.T.S. 279. The bulk of Convention 155 regards the creation of effective national, regional, and workplace mechanisms for implementation and compliance with other ILO standards. Id.

67. Id. at art. 4(2).

68. "Human rights are universal and inalienable; indivisible; interdependent and interrelated. They are universal because everyone is born with and possesses the same rights, regardless of where they live, their gender or race, or their religious, cultural or ethnic background." Human Rights Principles, UnITED NATIONS POPULATION FUND, 2005, http://www.unfpa.org/resources/humanrights-principles.

69. Annette Burkeen, Private Ordering and Institutional Choice: Defining the Role of Multinational Corporations in Promoting Global Labor Standards, 6 WASH. U. GLOB. STUD. L. REV. 205, 226 (2007). Core labor standards were clarified in the 1998 Declaration on Fundamental Principles and Rights at Work [hereinafter Declaration on Fundamental Principles] in an effort to gain global consensus on labor rights. The Declaration on Fundamental Principles identified four core principles: freedom of association and the right to collective bargaining, the elimination of forced labor, the abolition of child labor and the elimination of discrimination in employment. States must respect these core principles regardless of their stage of economic development or if they have ratified certain ILO conventions. See id. at 226-27.

70. INT'L LABOUR OFFICE, WOMEN AT WORK: TRENDS 20161 (2016).

71. ILO, DECENT WORK INDICATORS: GUIDELINES FOR PRODUCERS AND USERS OF Statistical AND Legal Framework Indicators (ILO MANuAl $2^{\text {ND }}$ Version) 19 (2013). The four strategic pillars of Decent Work are (i) International labour standards and fundamental principles and rights at work (ii) Employment creation (iii) Social protection and (iv) Social dialogue and tripartism. Id. 
non-core rights by privileging core rights and undermined ILO enforcement. ${ }^{72}$ Whether or not the creation of core rights had an effect on implementation of substantive rights, there is little evidence since the 1980s that later declarations and plans ${ }^{73}$ have reassessed the fundamental OSH approach to health needs and rights of women workers in light of massive social and economic changes caused by globalization. This approach addresses a long list of critical health and safety areas and sector specific risks. These include protections against asbestos and chemical exposure, prevention of occupational cancer, control of air pollution, reduction of noise and vibration in the work environment, and measures to prevent major industrial accidents. ${ }^{74}$ ILO conventions institute permanent processes for the continued improvement of occupational health and safety, the "building of preventive safety and health culture," and the establishment of occupational health services at businesses. ${ }^{75}$ In addition, with respect to women, the ILO conventions and recommendations have increasingly

72. Core standards responded to criticism of the ILO's lack of focus, as well as differentiated procedural rights (core rights) that were to be part of trade agreements from substantive standards that focused on outcomes and establishing a floor. See STEVE HugheS \& Nigel Haworth, INTERNATIONAL LABOR ORGANIZATION: COMING IN FROM THE COLD 53 (Thomas Weiss \& Rorden Wilkinson eds., Routledge Global Institutions 2010). International law scholar Philip Alston criticized the Declaration on Fundamental Principles on several grounds, including its creation of a hierarchy among labor standards and indeterminate principles whose relationships with ILO convention standards is also undefined. Alston also notes that legal commentators observed the very limited nature of the Declaration on Fundamental Principles and general consensus that these core labor standards should have included the right to a safe and healthy workplace, protection against abusive treatment, and others. Philip Alston, 'Core Labour Standards' and the Transformation of the International Labour Rights Regime, 15 EUR. J. INT’L L. 457, 483-95 (2004); see also Philip Alston, Facing Up to the Complexities of the ILO's Core Labour Standards Agenda 16 EuR. J. INT'L L. 467, 477-78 (2005); Joshua Castellino \& Sarah Bradshaw, Sustainable Development and Social Inclusion: Why A Changed Approach is Central to Combating Vulnerability 24 WASH. INT'L L. J. 459, 480 (2015) (arguing that just development models must include compliance with core labor standards, fair wages, and decent working conditions). But see Francis Maupain, Revitalization Not Retreat: The Real Potential of the 1998 ILO Declaration for the Universal Protection of Workers' Rights, 16 EuR. J. INT'L L. 439, 449 (2005) (stating that workplace safety and health cannot be deemed "fundamental rights" because they are not "enabling rights," procedural rights which allow workers to obtain other rights). Others argue that the declaration did not create a hierarchy in any constitutive way and the ILO continued operating as before in hearing complaints and adopting conventions without regard to core or non-core standards. See Hyde, supra note 65, at 169.

73. See generally ILO Convention Concerning the Promotional Framework for Occupational Safety and Health (No. 187), June 15, 2006, 2564 U.N.T.S. 291; INT'L LABOR ORG., ILO DEClARATION ON SOCIAL JUSTICE FOR A FAIR GlobalizATION (June 10, 2008), http://www.ilo.org/wcmsp5/groups/public/--dgreports/--

cabinet/documents/genericdocument/wcms_371208.pdf; ILO, PLAN OF ACTION (2010-2016) TO ACHIEVE WIDESPREAD RATIFICATION AND EFFECTIVE IMPLEMENTATION OF THE OCCUPATIONAL SAFETY AND HEALTH INSTRUMENTS (CONVENTION NO. 155, ITS 2002 PROTOCOL, AND CONVENTION No. 187)

(2010),

http://www.ilo.org/wcmsp5/groups/public/@ed_norm/@normes/documents/policy/wcms_125616.pd f; see also G.A. Res. 70/1, IJ 8.1-8.b, U.N. Doc. A/RES/70/1 (Oct. 21, 2015) (adopting the ILO Decent Work Agenda as part of the U.N. Sustainable Development Goals).

74. Benjamin Alli, Fundamental Principles of Occupational Health and Safety (2nd ed. 2008).

75. Id. at 10-12. 
addressed gender equity and anti-discrimination standards including equal pay for equal work ${ }^{76}$ and provisions against pregnancy discrimination and protection of maternity leave. ${ }^{77}$

Despite these protective provisions, OSH standards do not undertake the full range of issues and potential violations that women workers in global supply chains experience because of their gender. Feminist critiques of the ILO regime often criticize it for gender bias and the exclusion of women's experiences. ${ }^{78}$ Experts on gender, global value chains, and decent work, have noted that codes of conduct designed around ILO conventions and national labor legislation do not address gender issues that cross between the personal and workplace domains. ${ }^{79}$ The ILO Core Labor Standards are based on the concept of a 'male breadwinner' pursuing employment in the public sphere and a 'female caregiver' confined to the private sphere ${ }^{80}$ Others have criticized the ILO Core Labor Standards because, although they contain anti-discrimination provisions, they do not address how gender discrimination is inherent within the structures of many labor markets, particularly the garment industry. ${ }^{81}$

The gender bias of the OSH framework is reflected in the domestic legislation and labor movements of the ILO member countries. National labor legislation often focuses on employment that follows "male norms" and on permanent, full-time employment, ${ }^{82}$ which makes these regimes far less capable of dealing with the labor conditions of many women workers.

The issue of gender inequality within these markets leads to the exclusion of women's experiences, including health and reproductive health needs, in global supply chains by their employers and in legal regimes and social movements that seek to better the working conditions of these workers. For example, in one case study of maquiladora workers in Nicaragua, it was noted that trade unions did not have an understanding of the wider issues facing women workers in maquilas, or factories in export processing zones. ${ }^{83}$ This lack of understanding has led to the creation of women's organizations in Nicaragua

76. Equal Remuneration Convention (No. 100), June 29, 1951, 165 U.N.T.S. 303.

77. See generally Revision of the Maternity Protection Convention (No. 183), June 15, 2000, 2181 U.N.T.S. 253.

78. Castellino \& Bradshaw, supra note 72 , at 480.

79. Stephanie Barrientos et al., A Gendered Value Chain Approach to Codes of Conduct in African Horticulture, 31 WORLD DEV. 1511, 1517 (2003).

80. LEAH VOSKO, LAW COMMISSION OF CANADA, CONFRONTING THE NORM: GENDER AND INTERNATIONAL REGULATION OF PRECARIOUS WORK 2 (2004), http://publications.gc.ca/collections/Collection/JL2-27-2004E.pdf.

81. O'Konek, supra note 7, at 284.

82. Barrientos et al., supra note 79, at 1516.

83. MARINA PRIETO-CARRÓN, CENTRAL AMERICA WOMEN's NETWORK, SOCIAL REPRODUCTION AND LABOR RIGHTS: A CASE STUDY OF WOMEN WORKERS IN NiCARAGUA 2-3 (2010), http://cawn.org/assets/CAWN\%20briefing\%20Feb\%202010\%20Production\%20Reproduction.pdf. 
focused on addressing the connections between gender and labor issues. ${ }^{84}$ The ILO regime and national legal regimes, which inform human rights, fair trade, and corporate social accountability movements, fail to address the systemic barriers within these markets, foreclosing a rich exploration of the health rights of women at the workplace, let alone robust protection of these rights.

It is true that ILO conventions and OSH standards are meant to be a floor for labor rights ${ }^{85}$ and governments can nonetheless provide women workers with workplace protections that take into account their experiences. Nothing in OSH conventions prevents alignment with other health recommendations or national health authorities; in fact, there are recommendations that occupational safety programs promote prevention campaigns and collaborate within the framework of public health systems. ${ }^{86}$ Furthermore, the Better Work Programme of the ILO and International Finance Corporation, launched in 2007 to improve standards of performance in labour and working conditions and to conduct workplace monitoring, research, and education in eight countries, has an important focus on women, gender equality, and health. ${ }^{87}$ It has incorporated reproductive health in its training activities. ${ }^{88}$ In Cambodia, the Programme was for several years the implementing partner with Business for Social Responsibility of HERproject, a workplace initiative that provides women's reproductive and general health education. ${ }^{89}$

In practice, however, the current application of OSH standards through labor regulation and monitoring, whether by State agencies or private entities, emphasizes inputs such as the number of fire exits and extinguishers, the use of protective clothing, the number of health providers, and the existence of health stations or infirmaries. ${ }^{90}$ Though these are all essential concerns, there is little focus on broader health issues relevant to the workplace or on the practices and competence of workplace health providers in terms of what they actually dothe quality of care, the protocols used, and the treatment of patients. This

84. Id.

85. Barrientos et al., supra note 79, at 1516 (discussing how the ILO core conventions can supplement weak national legislation, providing a floor for labor rights); Occupational Health as a Human Right, ILO ENCYClOPEDIA OCCUPATIONAL HEALTH \& SAFETY (Feb. 15, 2011), http://www.iloencyclopaedia.org/part-iii-48230/resources-institutional-structural-and-legal/30-23resources-institutional-structural-and-legal/occupational-health-as-a-human-right.

86. Occupational Health Service Recommendation (No. 171) art. 24, June 26, 1985, 1498 U.N.T.S. 19. Art. 26 also notes: “. . .occupational health services might engage in other health activities, including curative medical care for workers and their families, as authorized by the competent authority in consultation with the most representative organisations of employers and workers, where they exist." Id. at art. 26.

87. Focus on Women, BETTER WORK, http://betterwork.org/global/?cat=92 (last visited Nov. 10, 2016).

88. Id.

89. Press Release: American Eagle Outfitters and Better Work Launch HERproject Initiative in Cambodia, BETTER WORK (Dec. 19, 2013), http://betterwork.org/global/wpcontent/uploads/AEOHERProjectCambodiaPressRelease-FINAL_1.pdf.

90. See, e.g., Bangladesh Labour Act of 2006, Chapter 8, Welfare Measures, number 89 (5). 
approach is not aligned with the quality of care movement of public health, which is strongly linked to a human rights framework for health practices focusing on availability, accessibility, acceptability, and quality of services ${ }^{91} \mathrm{It}$ is also not aligned with a more holistic view of the relationship between workplace and non-workplace health, which is implicit in the emphasis on the social determinants of health. ${ }^{92}$ Paul Schulte, a researcher and director at the National Institute for Occupational Safety and Health, Centers for Disease Control and Prevention, writes, "Many of the most prevalent and significant health-related conditions in workers are not caused solely by workplace hazards, but also result from a combination of work and nonwork factors ...."93 An example of this approach is the Total Worker Health program launched by the National Institute for Occupational Safety and Health in 2011 to focus on "how environmental, workplace factors can both mitigate and enhance overall worker health beyond traditional occupational safety and health concerns." 94

Today it is increasingly clear that a reconceptualization of workplace health is warranted to recognize the growing role of women in the global workforce, a reconceptualization that is important to all workers.

III.

\section{THE Right To HEALTH}

Health-related human rights are well-established in international human rights law and are more multi-faceted than the narrower workplace rights addressed by the international occupational health and safety standards. The right to health was incorporated in the World Health Organization Constitution adopted by 61 States in July 1946 and took force in June $1948,{ }^{95}$ thus "predat[ing] many of the other human rights in international law." 96 It was then

91. Karen Hardee et al., Voluntary, Human Rights-Based Family Planning: A Conceptual Framework, 45 STUD. IN FAM. PLAN. 1 (2014).

92. The World Health Organization defines social determinant of health in the Rio Political Declaration, endorsed by WHO Member States at the Sixty-fifth World Health Assembly (WHA) in May 2012, as "the conditions in which people are born, grow, live, work and age. These circumstances are shaped by the distribution of money, power and resources at global, national and local levels. The social determinants of health are mostly responsible for health inequities - the unfair and avoidable differences in health status seen within and between countries." WHO, RIO Political Declaration on Social Determinants of Health (2011), http://www.who.int/sdhconference/declaration/Rio_political_declaration.pdf.

93. Paul Schulte et al., Considerations for Incorporating "Well-Being” in Public Policy for Workers and Workplaces, 105 AM. J. PUB. HEALTH 31 (2015).

94. Total Worker Health, NAT'L InST. FOR OCCUPATIONAL SAFETY \& HEALTH, http://www.cdc.gov/niosh/twh/totalhealth.html (last visited Nov. 10, 2016).

95. Constitution Of WHO: Principles, World Health Organization, WHO (2016), http://www.who.int/about/mission/en (last visited Nov. 10, 2016).

96. Betty Yolanda \& CASEy B. Rubino, A.B.A, Rule of Law Initiative, The Asean HumAN RightS DEClARATION: A LEgAL ANALYSis (2014), http://www.americanbar.org/content/dam/aba/directories/roli/asean/asean-human-rights-declarationlegal-analysis-2014.authcheckdam.pdf. 
incorporated in the Universal Declaration of Human Rights (UDHR) adopted in December 1948.97 The understanding of the general right to health should provide the framework for addressing women's heath rights at work. This includes reproductive health, for which international human rights instruments offer a rather expansive explanation of what reproductive health entails and what it entitles women to access with respect to health care services. The right to health requires States to ensure that their citizens can exercise these rights as well as prevent violations of these rights by third parties. In this Part, we discuss provisions of international human rights that illuminate the comprehensive nature of the right to health and speak to the realities of women workers.

Internationally recognized human rights are set forth in the human rights legal system: a complex web of laws, policies, complaint procedures, and enforcement mechanisms. Human rights law operates on three levels: the international level with the United Nation's complicated and often overlapping bodies and mandates; the regional level with regional charters (such as the European Social Charter, the African Charter on Human and Peoples' Rights, and the Arab Charter on Human Rights); and the national level with national courts and human rights commissions.

Internationally recognized human rights are articulated in customary law and international treaties (also known as Conventions or Covenants). Declarations or other consensus documents that States sign on to can also contain recognized human rights. ${ }^{98}$ When States sign on to a treaty or covenant, they are committing themselves to follow the spirit of that document ${ }^{99}$ When States ratify a covenant they commit themselves to harmonizing their national laws in accordance with the principles contained in the document. ${ }^{100}$ That is, they agree to implement the principles of that document through their national laws.

In the UN human rights system, each of the seven human rights covenants has its own committee - or "treaty body" - that is charged with monitoring and enforcing that covenant. ${ }^{101}$ Some committees are authorized to hear complaints about rights violations. The committees are responsible for determining how the

97. Universal Declaration of Human Rights, art. 25, G.A. Res. 217 (III) A, U.N. Doc. A/RES/217(III) (Dec. 10, 1948).

98. Human Rights: A Basic Handbook for UN Staff, Office Of The High Commissioner For Human Rights, 2000, p. 5, https://www.un.org/ruleoflaw/blog/document/human-rights-a-basichandbook-for-un-staff (Feb. 6, 2017); PHILIP ALSTON \& RYAN GOODMAN, INTERNATIONAL HUMAN RIGHTS (2012).

99. Vienna Convention on the Law of Treaties, Art. 18, 26, May 23, 1969, 1155 U.N.T.S. 331, 8 I.L.M. 679.

100. Id. Human Rights: A Basic Handbook for UN Staff, Office Of The High Commissioner For Human Rights, 2000, p. 4, https://www.un.org/ruleoflaw/blog/document/human-rights-a-basichandbook-for-un-staff (Feb. 6, 2017).

101. Philip ALSTON \& RYAN GoOdMAn, supra note 98; Office of the United Nations High Commissioner for Hum. Rts., The United Nations Human Rights Treaty System, Fact Sheet No. 30/Rev. 1, 21 (2012), http://www.ohchr.org/Documents/Publications/FactSheet30Rev1.pdf. 
rights will be interpreted and implemented. They do this by issuing statements and comments, agreeing to hear certain complaints and dismissing others that it considers outside of their purview, and responding to country reports. ${ }^{102}$ Thus, it is through the issuing of "General Comments" and the offering of "Concluding Observations" in response to country reports that the substantive content of international human rights is interpreted, updated, and adapted to respond to changes in thinking and political and social circumstances.

The interpretation of rights also shifts as a result of changes in social attitudes and awareness of new ways that rights are abused. The advocacy efforts of NGOs and international human rights experts have also played an important role in getting previously unrecognized human rights recognized by the international community and included in the interpretation of the human rights treaties. ${ }^{103}$ For example, it was not until 1993, at the World Conference on Human Rights in Vienna, that women's rights activists reframed violations impacting women in the "private sphere," such as honor killings, child marriage, and violence against women, as human rights violations to be addressed systematically throughout the United Nations system. ${ }^{104}$

The entire interpretation of a right is not self-evident in a single covenant or comment. A right first may be established in one covenant and then be affirmed, expounded upon, or reinterpreted to address other violations in other instruments. For example, the right to health was initially enshrined in the Universal Declaration of Human Rights and its subsequent corresponding instrument, the International Covenant on Economic, Social and Cultural Rights (ICESCR). ${ }^{105}$ However, it is also stated as a right in the Convention on the Elimination of all Forms of Discrimination Against Women (CEDAW), which is intended to prohibit discrimination of the basis of sex. ${ }^{106}$ Similarly, some health-related rights, such as the right to access family planning information, are articulated in the ICESCR, and are also affirmed in other documents such as from the International Conference on Population and Development, which focused on population and family planning. ${ }^{107}$

102. Id

103. Non-State Actors as Standard Setters, (Anne Peters et al. eds., 2009); Steve Charnovitz, Nongovernmental Organizations and International Law, 100 AM. J. INT'L L. 348 (2006).

104. Charlotte Bunch, Legacy of Vienna: Feminism and Human Rights, Presentation at the International Expert Conference on Vienna + 20, 3-4 (June 27, 2013) (transcript available at http://www.cwgl.rutgers.edu/docman/coalition-building/620-legacy-of-vienna-feminism-andhuman-rights/file).

105. International Covenant on Economic, Social and Cultural Rights, Dec. 16, 1966, 999 U.N.T.S. 171 [hereinafter ICESCR].

106. Convention on the Elimination of All Forms of Discrimination against Women, Dec. 18, 1979, 1249 U.N.T.S. 13 [hereinafter CEDAW].

107. Report of the International Conference on Population and Development, International Conference on Population and Development, Cairo, Sept. 5-13, 1994, U.N. Doc. A/CONF.171/13. 
The inclusion of rights contained in one instrument in subsequent instruments serves to reinforce and strengthen broader recognition of the right. ${ }^{108}$ This cross-referencing of rights across different instruments reflects how these rights are interdependent and can only be fully realized when other rights are enjoyed. ${ }^{109}$ The more a right is repeated and affirmed in documents, the stronger the case can be made for actors to comply with it.

Although well established, health-related human rights are often overlooked in discussions about the impact of business activities on human rights. Until recently, governments and non-governmental human rights organizations in the West were far more preoccupied with so called "first generation" civil and political rights, than they were with "second generation" economic, social and cultural rights to which ILO conventions on occupational health speak. ${ }^{110}$ As a result, the application of economic, social, and cultural rights was underdeveloped compared to civil and political rights.

\section{A. The Right to Health in International Human Rights Law}

A right to health is found in international conventions and affirmed in regional instruments. ${ }^{111}$ These international conventions provide several protections of the right to health for women workers. Although not a legally binding instrument, ${ }^{112}$ the Universal Declaration of Human Rights first recognized the right to health in $1948 .{ }^{113}$ Article 25 states that everyone has a

108. Office of the United Nations High Commissioner for Hum. Rts., The United Nations Human Rights Treaty System, Fact Sheet No. 30/Rev. 1, 18 (2012), http://www.ohchr.org/Documents/Publications/FactSheet30Rev1.pdf.; PHILIP ALSTON \& RYAN GOODMAN, INTERNATIONAL HUMAN RIGHTS (2012).

109. Id.

110. Id.; Malcolm Shaw, International Law, 268-70 (2008); see also Frans Viljoen, International Human Rights Law: A Short History, UN Chronicle, (Jan. 2009), https:/unchronicle.un.org/article/international-human-rights-law-short-history.

111. Due to limitations of the article, we do not discuss the regional conventions and domestic laws that recognize and affirm a right to health. Regional conventions such as The American Convention on Human Rights in the Area of Economic, Social \& Cultural Rights Additional Protocol, the African Banjul Charter, and the Arab Charter on Human Rights explicitly declare a right to health, using the definition of the WHO Constitution. League of Arab States, Arab Charter on Human Rights, art. 39 (1)-(2)(a), March 15, 2008, reprinted in 12 INT'L HUM. RTS. REP. 893 (2005), https://www1.umn.edu/humanrts/instree/loas2005.html; Additional Protocol to the American Convention on Human Rights in the Area of Economic, Social \& Cultural Rights, art. 10, Nov. 16, 1999, O.A.S.T.S. No. 69; African (Banjul Charter) on Human and Peoples' Rights, art. 16, Oct. 21, 1986, 1520 U.N.T.S. 123. Finally, the European Social Charter has several articles which expressly and implicitly guarantee a right to health, including Articles 11 and 13, which provide for a right to public health, facilities for health promotion and education, and medical care for those who lack the resources to access this care. European Social Charter, Oct. 18, 1961 E.T.S. No. 035, http://www.coe.int/en/web/conventions/full-list/-/conventions/rms/090000168006b642.

112. The Universal Declaration of Human Rights [hereinafter UDHR] was adopted to exert a moral and political influence on states but many believe that specific provisions of the UDHR have become legal obligations under customary international law. INTERNATIONAL HUMAN RIGHTS IN CONTEXT: LAW, POLITICS, AND MORALS 135-137 (Philip Alston et al., eds., 2007).

113. Eight states abstained from voting on UDHR. Universal Declaration of Human Rights 
right to a "standard of living adequate for the health and well-being of himself and of his family," including the provision of medical care and necessary social services. ${ }^{114}$ The political climate at the time made the task of translating these principles into one document challenging, so the United Nation's Human Rights Commission created two treaties: the International Covenant on Civil and Political Rights (ICCPR); and the International Covenant on Economic, Social and Cultural Rights (ICESCR). The Declaration of Human Rights together with the ICCPR and the ICESCR comprise what is called the International Bill of Rights. Building on the UDHR, multiple UN treaties recognize the right to health and elaborate on its multiple aspects. We review the substantive content of the right to health in the major international instruments as relevant to the experiences of women workers in global supply chains below.

\section{The International Covenant on Economic, Social, and Cultural Rights ("ICESCR")}

While the right to health is listed as a human right in a number of UN covenants, the ICESCR is largely recognized as the primary covenant in which the right to health and health-related human rights are established. ${ }^{115}$ The ICESCR contains several protections that address the needs of women workers in global supply chains. These provisions discuss the social determinants of health, including the workplace, occupational health and safety, and the right to sexual and reproductive health. In addition, the ICESCR describes State obligations to guarantee that health goods, services, and information are accessible to all who reside in a State. These obligations may help inform how corporations ensure the right to health in their workplaces.

Article 12 of the ICESCR specifically focuses on health. ${ }^{116}$ Article 12 recognizes "the right of everyone to the enjoyment of the highest attainable standard of physical and mental health." 117 The ICESCR reiterates the definition of health found in the World Health Organization (WHO) Constitution and requires State parties to take steps necessary for the full realization of this right. ${ }^{118}$ The WHO Constitution defines health as a "state of complete physical,

Signatories, ETHIOPIA BLOG (Apr. 21, 2014), http://unethiopia.org/universal-declaration-of-humanrights-signatories.

114. Universal Declaration of Human Rights, art. 25, G.A. Res. 217 (III) A, U.N. Doc. A/RES/217(III) (Dec. 10, 1948).

115. There are 164 state parties to the ICESCR. ICESCR, Dec. 16, 1966, 999 U.N.T.S. 171; see also OfFICE OF THE UNITED NATIONS HIGH COMM'R FOR HuM. RTS. \& WORLD HEALTH ORG., THE Right TO HEALTH, FACT SHEET No. 31 (2008), http://www.ohchr.org/Documents/Publications/Factsheet31.pdf.

116. "The State Parties to the present Covenant recognize the right of everyone to the enjoyment of the highest attainable standard of physical and mental health." ICESCR, art. 12(1), Dec. 16, 1966, 999 U.N.T.S. 171. Art. 12(2) discusses steps that states must undertake to "achieve the full realization of this right." Id. at art. 12(2).

117. Id. at art. 12 .

118 Id. at art. 12(1)-(2). 
mental and social well-being and not merely the absence of disease or infirmity" and affirms that every person should enjoy the "highest attainable standard of health" regardless of their political belief, race, religion, or socioeconomic status. ${ }^{119}$

The ICESCR envisions the right to health as encompassing occupational health and safety, as well as sexual and reproductive health. For example, Article 7 of the ICESCR declares everyone has a right to safe and healthy working conditions. ${ }^{120}$ Under this convention, the workplace environment is a social determinant of health that must be considered to realize the right to health for all persons. ${ }^{121}$ Article 12 of the ICESCR protects the "improvement of environmental and industrial hygiene," the reduction of infant mortality, "prevention, treatment, and control of occupational disease," and conditions enabling equal access to medical services and attention. ${ }^{122}$

The crafters of the ICESCR recognized that resource constraints would prohibit States' ability to deliver on all of the health-related human rights immediately. Therefore, the ICESCR did not require that States immediately fulfill these obligations. Instead, this covenant was subject to progressive realization, meaning that States were required to take immediate action within their financial limitations and other constraints to realize the right to health. They were, therefore, required to take "all appropriate means" to achieve the realization of the rights contained in the covenant, which are understood to include the adoption of "legislation measures" and other means. ${ }^{123}$

The Committee that monitors the ICESCR engages in an ongoing process of updating the interpretation of the rights contained in the covenant in response to new thinking or new definitions of what might be considered a right or a violation. In 2000, the Committee on Economic, Social and Cultural Rights issued General Comments reflecting new thinking about women's health and reproductive rights that emerged out of the Vienna Conference on Human

119. Constitution of the World Health Organization, July 22, 1946, 62 Stat. 2679, 14 U.N.T.S. 185 (entered into force Apr. 7, 1948), http://www.who.int/governance/eb/who_constitution_en.pdf.

120. ICESCR, art 7(b), Dec. 16, 1966, 999 U.N.T.S. 171 ("The State Parties to the present Covenant recognize the right of everyone to the enjoyment of just and favourable conditions of work which ensure, in particular ... safe and healthy working conditions.")

121. The Committee on Economic, Social, and Cultural Rights (CESR) has commented that States have the duty to address determinants of health, such as: (1) access to safe drinking water and adequate sanitation; (2) safe food; (3) adequate nutrition and housing; (4) healthy working and environmental conditions; and (5) health-related education and information, including on sexual and reproductive health. Comm. Econ., Soc. and Cultural Rights, CESCR General Comment 14: The Right to the Highest Attainable Standard of Health (Art. 12), IJ 11, UN Doc. E/C.12/2000/4 (2000) [hereinafter "General Comment 14"].

122. ICESCR, art. 12(2)(a-d), Dec. 16, 1966, 999 U.N.T.S. 171 (obliging state parties to take measures to improve industrial hygiene and prevent, treat, and control occupational diseases).

123. U.N. Comm. on Econ., Soc., and Cultural Rights (CESCR), General Comment 3: The Nature of States Parties' Obligations (Art. 2, Para. 1, of the Covenant), IJ 2-3, U.N. Doc. E/1991/23 (Dec. 14, 1990). 
Rights, the International Conference on Population and Development (Cairo 1994) and the Fourth World Conference on Women (Beijing 1995). ${ }^{124}$

Almost fifty years after the ICESCR was first crafted, the Committee issued General Comment $14^{125}$ which included a number of important clarifications on the right to health. First, it acknowledged "that the right to health embraces a wide range of socio-economic factors that promote conditions in which people can lead a healthy life, and extends to the underlying determinants of health." 126 These determinants include "access to safe and potable water and adequate sanitation, an adequate supply of safe food, nutrition and housing, healthy occupational and environmental conditions, and access to health-related education and information, including on sexual and reproductive health." 127

Second, the Comment clarified that the Committee interprets the treaty provision related to infant mortality and child development to be understood "as requiring measures to improve child and maternal health, sexual and reproductive health services, including access to family planning, pre- and postnatal care, emergency obstetric services and access to information, as well as to resources necessary to act on that information." 128 The Committee also made clear that people should have access to "health-related education and information." 129

Third, the Committee specifically recognized the right of individuals to make their own reproductive decisions and to control their own bodies as part of the right to health. It noted that "[t]he right to health contains both freedoms and entitlements. The freedoms include the right to control one's health and body, including sexual and reproductive freedom." 130 In addition, the right to reproductive and sexual health has been recognized in the International Covenant on Civil and Political Rights (ICCPR). Under the ICCPR, the right to

124. General Comment 14, supra note 121.

125. Id.

126. Id. 94.

127. Id. I 11.

128. Id. I 14 (italics added).

129. Id. 11 (italics added).

130. Id. I 8. 
sexual and reproductive health is connected to the right to life ${ }^{131}$ and to rights of nondiscrimination, equality, and privacy. ${ }^{132}$

Fourth, with respect to the provision on environmental and industrial hygiene, the Committee explained in its General Comments that the provision should be interpreted to mean: preventive measures regarding occupational accidents and disease; an adequate supply of safe and potable water; basic sanitation; the prevention and reduction of exposure to harmful substances and environmental conditions that impact human health; and the reduction of factors contributing to workplace health hazards. ${ }^{133}$ The Committee further commented in Article 12 on protections for workers such as adequate housing, safe and hygienic working conditions, adequate supply of food and proper nutrition, and discouraging unhealthy behaviors such as alcoholism and drugs. ${ }^{134}$ This guidance goes beyond the traditional requirements of occupational health and safety by providing protections that increase the mental, physical, and social wellbeing of a worker.

\section{The Availability, Accessibility, Acceptability, and Quality (AAAQ) Framework}

General Comment 14 elaborates on the idea that the right to health must be operationalized by the State so that persons can enjoy and meet the highest standard of health possible as individuals. This idea is elaborated in the AAAQ Framework established by General Comment $14 .{ }^{135}$ The AAAQ Framework requires States to ensure that the facilities, goods, services, and conditions needed for health are accessible, available, acceptable, and of quality..$^{136}$

Under the AAAQ Framework, "availability" means that functioning public health and healthcare facilities, goods, services and programs are available in sufficient supply within the State, ${ }^{137}$ including essential medicine such as contraception. ${ }^{138}$ The "availability" prong also includes safe and potable

131. The UN Human Rights Committee for the International Covenant on Civil and Political Rights has utilized the right to life in Article 6 of ICCPR to declare that state parties have obligations regarding maternal mortality and unwanted pregnancies, as well as the responsibility to adopt measures to reduce infant mortality and increase life expectancy. The right to life is therefore interdependent with a right to health, including sexual and reproductive health. U.N. Human Rights Comm., General Comment No. 28: Equality of Rights Between Men and Women (Article 3), I 10, U.N. Doc. CCPR/C/21/Rev.1/Add.10 (Mar. 29, 2000) [hereinafter General Comment 28]; U.N. Human Rights Comm., CCPR General Comment No. 6: Article 6 (Right to Life), I 5, U.N. Doc. HRI/GEN/1/Rev.1 at 6 (1994).

132. General Comment 28, supra note 131 , 9J 3, 20 (paragraph 20 discusses equality and the right to privacy in regards to a woman's sexual life).

133. General Comment 14, supra note 121, IJ 14-15.

134. Id.

135. Id. 99

136. Id. II 12(a)-(d).

137. Id. 12 (a)

138. CTR. FOR REPRODUCTIVE RIGHTS, SUBSTANTIVE EQUALITY AND REPRODUCTIVE RIGHTS: 
drinking water, adequate sanitation facilities, hospitals, clinics, and other healthrelated buildings, as well as trained medical and professional staff receiving competitive salaries. ${ }^{139}$

"Accessibility" requires facilities, goods, and services to be economically affordable and geographically, safely, and physically accessible for all. ${ }^{140}$ Accessibility to services and facilities must be legally and practically ensured, particularly for marginalized communities. ${ }^{141}$ Non-discrimination and access to seek, receive, and deliver information and ideas are part of the accessibility requirement of the AAAQ Framework. ${ }^{142}$

The "acceptability" prong emphasizes culturally appropriate services, goods, and facilities, which are respectful of the needs of persons of various genders and ages ${ }^{143}$ and consider the needs of marginalized communities. ${ }^{144}$ In addition, this requirement mandates that services, goods, and facilities be designed to improve the health status of the individuals and communities concerned. ${ }^{145}$

"Quality" refers to the State's obligation to guarantee that all health facilities, goods and services are culturally, scientifically, and medically appropriate, as well as considerate of medical ethics. ${ }^{146}$ This definition of "quality" includes scientifically approved and unexpired medications and equipment. It also reiterates the requirements of safe and potable drinking water, adequate sanitation, and skilled medical staff. ${ }^{147}$

As a central part of public health, the AAAQ framework is integrated into new development initiatives such as Family Planning 2020, among others, and its Rights and Empowerment Principles for Family Planning. ${ }^{148}$ Family Planning 2020 articulates that individuals are agents in their reproductive lives and must have access to information, services, and supplies to make these decisions. ${ }^{149}$

\footnotetext{
A Briefing Paper on Aligning Development Goals With Human Rights Obligations 9 (2014), https://www.reproductiverights.org/sites/crr.civicactions.net/files/documents/Equality_Guide_Reduc ed_size.pdf.

139. General Comment 14, supra note 121, I 12(a).

140. Id. IJ 12(b)(ii)-(iii).

141. Id. I 12(b)(i).

142. Id. IJ 12(b)(i), (iv).

143. Id. I 12(c).

144. CTR. FOR REPRODUCTIVE RIGHTS, supra note 138, at 9.

145. General Comment 14, supra note 121, I 12(c).

146. Id. IJ 12(a), (c), (d).

147. Id. I 12(d).

148. See Jan Kumar \& Karen Hardee, Rights-Based Family Planning: 10 Resources TO Guide PROGRAMMing (May 2015), http://evidenceproject.popcouncil.org/wpcontent/uploads/2015/07/Resource-Guide-of-RBA-to-FP.pdf (discussing various family planning and contraceptive services guidelines).

149. Family Planning 2020, Rights and EMPOWERment Principles for Family PLANNING (2014), http://www.familyplanning2020.org/resources/4697.
} 
The ICESCR and the General Comments of the Committee are seen by family planning leaders as part of the array of human rights instruments that "can be used to hold governments accountable and to guide policies and programswhether in the public, not-for-profit, or private sectors." 150

Through these General Comments, the Committee has recognized how determinants of health, including the workplace, impact one's ability to attain a standard of health. In short, under the ICESCR, the right to health entitles everyone to safe and sanitary living and working conditions, support for sexual and reproductive health, and a quality health care system that fights diseases, provides medical services to everyone, and disseminates health information.

\section{The Convention on the Elimination of All Forms of Discrimination against Women ("CEDAW")}

Other international human rights instruments recognize the right to sexual and reproductive health. The Convention on the Elimination of All Forms of Discrimination Against Women (CEDAW) recognizes the right to health and reviews the responsibilities of governments to ensure this right is protected, particularly for women. ${ }^{151}$ CEDAW sets forth what actions are necessary (and what health-related services are required) for the State to provide in order to ensure that women are able to realize their right to health "on the basis of equality of men and women." ${ }^{152}$ It does not establish new health-related rights or give women special rights above and beyond those accorded to men. The Committee on CEDAW has affirmed that "access to health care, including reproductive health, is a basic right under CEDAW." 153

Like the ICESCR, CEDAW distinguishes between rights at work and within the workplace and the right to health by placing them in different articles. It reiterates and affirms a number of rights that affect health in the workplace that are established in the ICESCR, providing protections for pregnancy, maternity leave, and harmful work assignments. ${ }^{154}$ It also spells out what the State needs to do to ensure that the distinct health-related needs of women are met. CEDAW declares that State parties will implement measures to ensure that women have access to health care services and information, including services

150. Karen Hardee et al., Voluntary, Human Rights-Based Family Planning: A Conceptual Framework, 45 STUD. FAM. PLAN. 1, 4 (2014).

151 CEDAW, supra note 106, art. 12(1) ("States Parties shall take all appropriate measures to eliminate discrimination against women in the field of health care in order to ensure, on a basis of equality of men and women, access to health care services, including those related to family planning.").

152. Id. at arts. 10(h), 12 .

153. U.N. Comm. on the Elimination of Discrimination Against Women, CEDAW General Recommendation No. 24: Article 12 of the Convention (Women and Health), I 1, U.N. Doc. A/54/38/Rev.1, (1999) [hereinafter CEDAW General Comment 24].

154. CEDAW, supra note 106, art. 11(2). 
and information regarding family planning, free from discrimination. ${ }^{155}$ It also reiterates this State obligation for rural women. ${ }^{156}$

Finally, under CEDAW, discrimination has occurred if State parties refuse to legally provide certain reproductive health services. ${ }^{157}$ State parties to CEDAW must consider the health needs of women in vulnerable populations, noting that societal factors impact an individual's health status. ${ }^{158}$ State parties must eliminate discrimination against women, throughout all stages of life, when accessing health care services, especially at points in time when women are planning their families. ${ }^{159}$ As the Committee that monitors the implementation of CEDAW has been particularly focused on the application of rights to women, its General Comments help explain how the rights established in other treaties can apply to the unique circumstances of women. ${ }^{160}$

\section{Other Treaties That Support a Right to Health and Sexual and Reproductive Health}

Other specialized human rights conventions focused on various vulnerable populations also affirm the broad health-related human rights contained in the ICESCR - in particular, mental health, sexual and reproductive health, and maternal health, as well as the right to family planning information and services and the right to reproductive decision making and agency. These conventions may provide further protections of the right to health for women workers in global supply chains. These instruments include:

- The 1963 Convention on the Elimination of All Forms of Racial Discrimination (CERD). The CERD was the first covenant to affirm the right to health that was contained in the ICESCR. ${ }^{161}$ Article 5 of the CERD obligates State parties to prohibit and eliminate discrimination and guarantee specific, civil, political, economic, social, and cultural rights to everyone without distinction as to race, color, and ethnic origin. ${ }^{162}$ It also specifically mentions the right to public health services and medical care. ${ }^{163}$

155. Id. at art. 10(h).

156. Id. at art. 14(2)(b).

157. CEDAW General Comment 24, supra note 153, 11.

158. Id. I 6 .

159. Id. 92 .

160. See, e.g., CEDAW General Comment 24, supra note 153; U.N. Comm. on the Elimination of Discrimination Against Women, General Recommendation No. 23: Political and Public Life, U.N. Doc. A/52/38 (1997); U.N. Comm. on the Elimination of Discrimination Against Women, General Recommendation No. 13: Equal Renumeration of Work of Equal Value, U.N. Doc. A/44/38 (1989).

161. International Convention on the Elimination of All Forms of Racial Discrimination, art. 5(e)(iv), Dec. 21, 1965, 993 U.N.T.S. 3.

162. Id. at art. 5 .

163. Id. at art. 5(e)(iv). 
- The 1989 Convention on the Rights of the Child (CRC). The CRC guarantees children the right to health as it is defined in the ICESCR, which includes access to health information. ${ }^{164}$ The CRC clearly states no child should be denied access to health care. ${ }^{165}$

- The 1990 International Convention on the Protection of the Rights of All Migrant Workers and Members of their Families. The Convention does not obligate States to protect the migrant's right to health in a manner consistent with ICESCR, but it does require States to ensure that companies provide migrants with the same conditions of work that they are required to provide nationals, thus covering occupational safety and health rights. ${ }^{166}$

- The 2006 Convention on the Rights of Persons with Disabilities. This convention was meant to prevent discrimination, not create new rights. It reaffirms health rights by making specific reference to health care services "in the area of sexual and reproductive health and populationbased public health programmes," and requiring "health professionals to provide care of the same quality to persons with disabilities as to others." 167

\section{The Right to Health in International Policy}

Beyond binding international human rights instruments there are health rights contained in various global declarations and action plans. These instruments further elaborate on the right to sexual and reproductive health for women workers in global supply chains. While not legally binding, documents from the United Nation's world conferences, which bring together governments and civil society, represent an accepted global consensus on how rights are interpreted, and often lay out priority actions for governments to take to implement their human rights obligations. ${ }^{168}$ The world conferences are important because they provide an opportunity for the global community to establish new interpretations of rights, and, in this way, they move the human rights discourse forward. While many conferences are germane to our

164. Convention on the Rights of the Child, arts. 24(1) \& 24(2)(e), Nov. 20, 1989, 1577 U.N.T.S. 3

165. Id. at art. 24(1).

166. International Convention on the Protection of the Rights of All Migrant Workers and Members of their Families, art. 25(1)(a), Dec. 18, 1990, 2220 U.N.T.S. 3.

167. Convention on the Rights of Persons with Disabilities, art. 25, Dec. 13, 2006, 2515 U.N.T.S. 3.

168. See Johanna E. Bond, International Intersectionality: A Theoretical and Pragmatic Exploration of Women's International Human Rights Violations, 52 EMORY L.J. 71, 92 (2003) (“The [Beijing] Platform for Action is not a binding legal instrument, [but] it represents a global agenda for change that women's rights activists have used to agitate for reform in their own countries."); Sarah R. Hamilton, The Status of Women in Chile: Violations of Human Rights and Recourse Under International Law, 25 WOMEN's RTS. L. REP. 111, 115 (2004) (noting that "consensus decisions reached at international meetings are not formally binding"). 
consideration of the health rights of women workers, three are of particular importance.

The World Conference on Human Rights in Vienna in $1993^{169}$ was the first significant attempt for countries to gather and collectively review and update the human rights framework since the 1960s and the end of the Cold War. ${ }^{170} \mathrm{It}$ represented a "tipping point" for women's rights and health rights ${ }^{171}$ and was where the claim "women's rights are human rights" was first made. Vienna "challenged the artificial hierarchy placing civil and political over economic and social rights," 172 breaking down outdated divisions that existed during the Cold War. ${ }^{173}$ The conference recognized that all human rights are "indivisible" and should therefore been seen as carrying equal importance. It also shifted thinking about the State's role in protecting human rights. Rather than an obligation not to violate the rights of its citizens, now the State could be held responsible for its failure to adequately protect its citizens from infringements upon their rights by third parties. ${ }^{174}$

The idea that "women's rights are human rights" was used in 1994 and 1995 by activists at two major international conferences, the International Conference on Population and Development Program of Action ("ICPDPOA") and The Beijing Platform for Action at the U.N. Fourth World Conference on Women ("Beijing Platform"), to set a global agenda for women's rights, including sexual and reproductive health. ${ }^{175}$ Recognizing persistent discrimination against women-particularly in the workplace-threats to women's health, and lack of access to adequate education, the ICPDPOA and the Beijing Platform laid out programs of action to reverse these trends.

In the ICPDPOA, the purpose of sexual health was described as "the enhancement of life and personal relations, and not merely counseling and care

169. United Nations Human Rights Office of the High Comm'r, World Conference on Human Rights, 14-25 June 1993, Vienna, Austria, http://www.ohchr.org/EN/ABOUTUS/Pages/ViennaWC.aspx (last visited Nov. 7, 2016).

170. Navi Pillay, Twenty years working for your rights; the 1993 world conference on human rights, at 9, United Nations High Commissioner for Human Rights, United Nations, Geneva, 2013

171. Charlotte Bunch, Vienna's legacy: feminism and human rights, in CENTER FOR ECONOMIC AND SOCIAL RightS, TWENTY YEARS OF ECONOMIC AND SOCIAL RIGHTS ADVOCACY: MARKING THE TWIN ANNIVERSARIES OF THE CENTER FOR ECONOMIC AND SOCIAL RIGHTS AND THE VIENNA DECLARATION AND PROGRAM OF ACTION 36 (2015).

172. Navi Pillay, supra note 170 at 9 .

173. Ignazio Saiz, Introduction, in CENTER FOR ECONOMIC AND SOCIAL RighTS, TwENTY YEARS OF ECONOMIC AND SOCIAL RIGHTS ADVOCACY: MARKING THE TWIN ANNIVERSARIES OF THE CENTER FOR ECONOMIC AND SOCIAL RightS AND the VienNa DECLARATION AND PROGRAM OF ACTION 7 (2015).

174. Navi Pillay, supra note 170 at 9 .

175. Susan Tolmay, Vienna +20 - The World has Changed Considerably, as Women's Rights are Taken More Seriously as Human Rights, Ass'N FOR WOMEN'S RigHTS DEV. (June 27, 2013), https://www .awid.org/news-and-analysis/vienna-20-world-has-changed-considerably-womensrights-are-taken-more-seriously (interviewing with Charlotte Bunch). 
related to reproduction and sexually transmitted diseases"176 and it was included as part of reproductive health. ${ }^{177}$ This right to sexual health is inclusive of and indivisible from other health rights: the right to life, liberty and the security of the person; the right to health care and information; the right to nondiscrimination in the allocation of resources to health services and in their availability and accessibility; the rights to autonomy and privacy in making sexual and reproductive decision-making; and the rights to informed consent and confidentiality in relation to health services. ${ }^{178}$

The ICPDPOA affirmed that reproductive rights include "the right to attain the highest standard of sexual and reproductive health."179 To achieve this standard, the ICPDPOA stated that men and women need to have information on sexual and reproductive health; access to family planning methods of their choice that are safe, effective, affordable, and acceptable; other legal methods of regulating fertility; and access to appropriate health care services. ${ }^{180}$ The ICPDPOA stated that men and women need to be free from discrimination, coercion, and violence to exercise their rights to reproductive and sexual health. ${ }^{181}$

Moreover, the ICPDPOA urged governments and employers to eliminate gender discrimination in hiring, wages, benefits, training, and job security. ${ }^{182}$ It also outlined a plan that, among other directives, called for an end to discrimination based on pregnancy status and a means for women to combine childbearing, child rearing, and breastfeeding with employment. ${ }^{183}$

The Beijing Platform, adopted by 189 delegations, ${ }^{184}$ reiterated that women have a right to health. ${ }^{185}$ It connected the right to health to a woman's well-

176. Eszter Kismödi et al., Advancing Sexual Health Through Human Rights: The Role of the Law, 10 Glob. Public Health 252, 252 (2015).

177. Id.

178. Carmel Shalev, Right to Sexual and Reproductive Health - the ICPD and the Convention on the Elimination of All Forms of Discrimination Against Women, International Conference on Reproductive Health, Mumbai, India (Mar. 15-19, 1988), http://www.un.org/womenwatch/daw/csw/shalev.htm. Although there is no formal, international consensus on the definition of the term "sexual rights," there is an understanding that these rights are based in human rights recognized in international and regional instruments and national constitutions and laws, thereby obliging states to respect, protect, and fulfill these rights. See, e.g., Kismödi, supra note 176 , at 253 .

179. International Conference on Population and Development, Cairo, Egypt, Sept. 5-13, 1994, Report of the International Conference on Population and Development, I 4.1, U.N. Doc. A/CONF.171/13/Rev.1 (1995),

http://www.unfpa.org/webdav/site/global/shared/documents/publications/2004/icpd_eng.pdf.

180. Id. I 7.2.

181. Id. 97.3 .

182. Id. I 4.7 .

183. Id. I 4.4(f)-(g).

184. What is SRHR?, WOMEN WIN, http://guides.womenwin.org/srhr/what-is-srhr (last visited May 29, 2015).

185. Fourth World Conference on Women, Beijing Declaration and Platform for Action, $\mathbf{9}$ 89, 
being and her ability to participate in public and private life. ${ }^{186}$ It also called on governments to increase a woman's access throughout her lifespan to appropriate, affordable, and quality health care, information, and services; ${ }^{187}$ strengthen women's health promotion programs; ${ }^{188}$ and implement genderspecific initiatives that address sexually transmitted diseases, HIV/AIDS, and sexual and reproductive health concerns ${ }^{189}$ among other tasks.

Similar to the ICPDPOA, the Beijing Platform later expanded and further clarified a plan to end discrimination against women in the workplace. ${ }^{190}$ The declaration outlined a list of actions by government, private, and nongovernmental stakeholders to ensure that women have equal access to employment, education, and professional training. ${ }^{191}$ Further actions were listed that would strengthen women's economic capacity, eliminate occupational segregation, and promote harmonization of work and family responsibilities. ${ }^{192}$

Gita Sen of the Harvard School of Public Health notes, "Vienna, Cairo and Beijing (as these conferences are colloquially called) thus affirmed a more inclusive meaning for the right to health: for women and girls, in particular, the right to health is not only about obtaining health services or providing nutrition, clean water and sanitation but also the right to health includes the right to decision-making, control, autonomy, choice, bodily integrity and freedom from violence and fear of violence. States have a responsibility not only to provide access to health services but also to respect, protect and fulfill the above aspects of women's and girls' human rights vis-à-vis States' own actions as well as those of families, communities and the private sector." 193

\section{B. Other International Declarations, Frameworks, and Initiatives on Workplace Health}

International and European discourse ${ }^{194}$ have long recognized the need for States and corporate employers to improve a worker's overall health by going

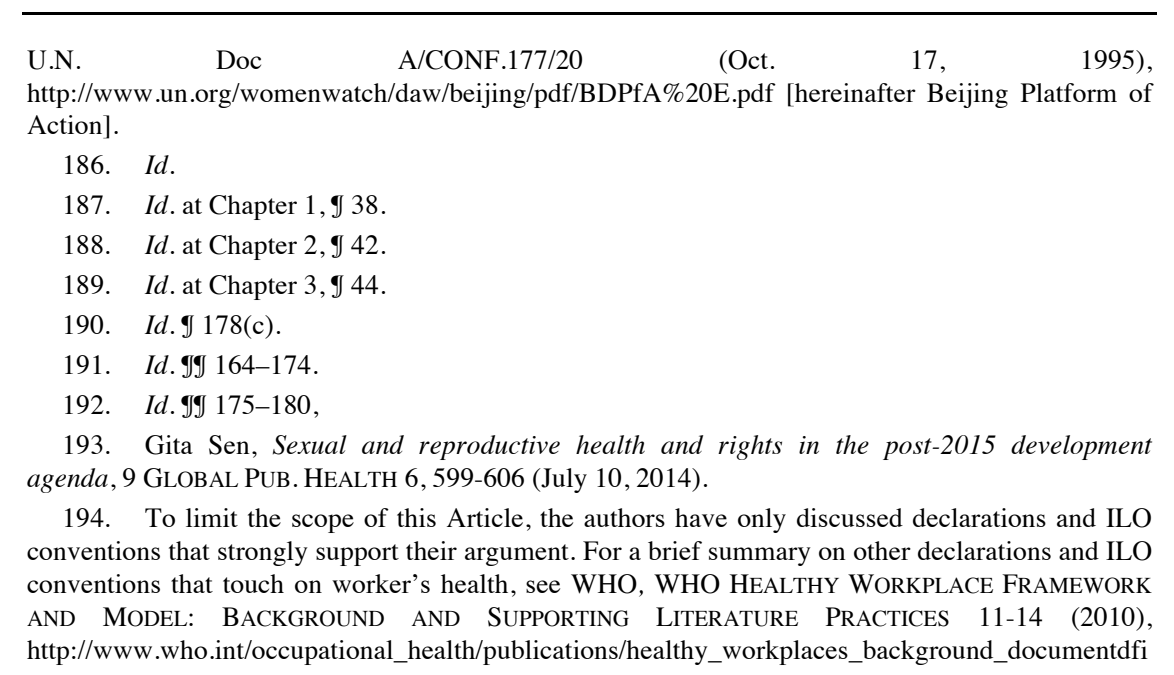


beyond their occupational safety and health obligations. A range of international frameworks and initiatives have also suggested a broader concept of occupational health and safety consideration that corporate actors should fulfill. These have recognized the multifaceted nature of the right to health for women workers in global supply chains. Various declarations and charters have also emphasized how the workplace impacts reproductive health and well-being.

Most notably, the Moscow Declaration/Position Statement on Reproductive Health at Work ("Moscow Declaration") adopted by the International Conference: Medical and Ecological Problems of Workers' Reproductive Health in 1998 provided a robust discussion on what states should do to mitigate the impacts of the workplace on reproductive health. The Moscow Declaration called for a plan of action to ensure primary care and a new international convention addressing reproductive health in the workplace. ${ }^{195}$ Reproductive health was also addressed in the 2005 Bangkok Charter for Health Promotion in a Globalized World ("Bangkok Charter"). The Bangkok Charter notes that the health of men and women is impacted differently in a globalized world ${ }^{196}$ and, for the first time, explicitly recognizes that employers and corporations should practice health promotion in the workplace, calling it "a requirement for good corporate practice."197

Other European declarations have highlighted how the workplace is a social determinant of health and that workplace practices impact not only a person's mental health, but also their life outside of work. In 1997, the European Union in The Luxembourg Declaration on Workplace Health Promotion observed that attention only to occupational safety would not address health issues arising from globalization, changes in employment practices, and recent changes in the economy. ${ }^{198}$ It noted that solving these issues requires improvements to organizational work structure, promoting active participation at work, and support of personal development. ${ }^{199}$ The Barcelona Declaration on Developing Good Workplace Health Practice in Europe ("Barcelona Declaration") in 2002 further recognized that the workplace impacts family life before and after work hours and that many mental health disorders are linked to

nal.pdf.

195. Ilise L. Feitshans, Is There a Human Right to Reproductive Health?, 8 TEX. J. WOMEN \& L. 93, 115 (1998). The Declaration also includes prohibition or reduction of harmful occupational and environmental hazards, particularly for those who are contemplating parenting; research into environmental and occupational factors affecting reproductive health; and legal analysis of existing foreign and international laws on reproductive health.

196. , The Bangkok Charter for Health Promotion in a Globalized World, WHO (Aug. 11, 2005), http://www.who.int/healthpromotion/conferences/6gchp/bangkok_charter/en/.

197. Id. The Bangkok Charter also states that health promotion should be a core responsibility for all levels of government.

198. European Network for Workplace Health Promotion, The LuXembourg DeClaration ON WorkPlace Health Promotion in the European Union (2007), http://www.eon.com/content/dam/eon-com/en/downloads///Luxembourg_Declaration.pdf.

199. Id. 
stress from work. ${ }^{200}$ It suggested that the world of work may be the single, strongest social determinant of health. ${ }^{201}$

The World Health Organization has produced declarations and frameworks which recognize that occupational health and safety in the workplace does not solely determine the health outcomes and well-being of workers. These instruments have called on employers to have a comprehensive approach to improving workers' health and discussing the importance of improving the health of workers' families and their communities. Their 1994 strategy on occupational health for all explicitly recognized that occupational health has developed from a "monodisciplinary risk-oriented activity to a multidisciplinary and comprehensive approach" that considers a person's "physical, mental, and social well-being, general health, and development." 202 In 2006, the World Health Organization, in discussing their 1994 strategy, produced the Stresa Declaration on Workers Health, stating:

There is increasing evidence that workers' health is determined not only by the traditional and newly emerging occupational health risks, but also by social inequalities such as employment status, income, gender and race, as well as by health-related behaviour and access to health services. Therefore, further improvement of the health of workers requires a holistic approach, combining occupational health and safety with disease prevention, health promotion and tackling social determinants of health and reaching out to workers, families, and communities. ${ }^{203}$

Building on the Stresa Declaration and the 1996 plan, the World Health Assembly then endorsed a global 10-year plan, "Worker's Health: global plan of action." To further the objectives of this plan of action, the WHO produced a framework for States and employers, including those in the private sector, to create healthy workplaces that address workers' health and social well-being. ${ }^{204}$ The WHO Healthy Workplace Framework provided the following definition:

A healthy workplace is one in which workers and managers collaborate to use a continual improvement process to protect and promote the health, safety and well-being of workers and the sustainability of the workplace by considering the following, based on identified needs: health and safety concerns in the physical work environment; health, safety and well-being concerns in the psychosocial work environment including organization of work and workplace culture; personal health resources in the workplace; and ways of participating in the

200. European Network for Workplace Health Promotion, The Barcelona Declaration on Developing Good Workplace Health Practice in Europe (2002), http://www.ver.is/whp/pdf/barcelona.pdf.

201. Id.

202. WhO, Global Strategy on Occupational Health for All: The Way to Health AT WORK IJ 71 (1994), http://www.who.int/occupational_health/en/oehstrategy.pdf.

203. Who, Declaration on Workers Health Approved at the SeVenth MeEting of the WhO COllaborating Centres FOR OCcupational Health (2006), http://www.who.int/occupational_health/Declarwh.pdf.

204. HEALTHY WORKPLACE FRAMEWORK, supra note 194, at 16. 
community to improve the health of workers, their families and other members of the community. ${ }^{205}$

The Healthy Workplace Framework provides proactive recommendations for employers to ensure that the workplace improves the health of workers by looking at factors outside of occupational health and safety. It stresses that "personal health resources in the workplace" include a supportive environment; monitoring and support for continuous physical and mental health; and employer provision of health services, information, resources, and opportunities and flexibility so that "workers can support or motivate their efforts to improve or maintain healthy personal lifestyle practices." 206 In addition, the Healthy Workplace Framework emphasizes that businesses and employees are part of their immediate, local environments and communities and that these necessarily impact the health of employees and their families. ${ }^{207}$ This framework urges businesses to provide activities, expertise, and resources to the social and physical communities that impact the physical and mental health, safety, and well-being of its workers and their family members. ${ }^{208}$ It is notable that the ILO's Plan of Action 2010-2016 on OSH conventions and protocols adopts none of the more encompassing WHO language such as "holistic approach" and "health promotion" or "participating in the community to improve the health of workers."209

In addition to the abovementioned frameworks, that the gender equality and women's empowerment agenda of the United Nations has incorporated into their corporate social responsibility efforts provides additional insight regarding the role of corporations in ensuring the right to health for women workers. For instance, the focus on women's equality at the workplace has been advanced jointly by UN Women and the UN Global Compact with the launch of the Women's Empowerment Principles (WEPs) in 2010. ${ }^{210}$ The Global Compact is the largest, voluntary corporate sustainability initiative with 9,000 corporate signatories in 135 countries $^{211}$ that commit to applying social responsibility business practices to their operations. The seven principles, designed to promote corporate policies that advance women's empowerment globally are based on the Calvert Women's Principles launched in 2004 to address the need for private sector organizations to meaningfully engage and shape conversations and efforts

\footnotetext{
205. Id.

206. Id. at 93 .

207. Id. at 94 .

208. Id. at 94-95.

209. Plan of Action (2010-2016) to achieve widespread ratification and effective implementation of the occupational safety and health instruments (Convention No. 155, its 2002 Protocol and Convention No. 187), ILO (2010), http://www.ilo.org/global/standards/WCMS_125616/lang_en/index.htm.

210. About Us, WOMEN'S EMPOWERMENT PRINCIPLES, http://www.weprinciples.org/Site/Faq/\#2 (last visited November 3, 2016).

211. Our Participants, UN GLOBAL COMPACT, https://www.unglobalcompact.org/what-isgc/participants, (last visited on November 3, 2016).
} 
on women's equality. ${ }^{212}$ Principle 3 addresses workplace health and ensuring the health, safety, and well-being of women and men workers. Several other WEPs are relevant to women working in global supply chains and promote education, training, and professional development for women; the fair treatment of women and men; and respect for human rights and nondiscrimination policies. ${ }^{213}$ In 2014, the Global Compact and UNWomen released a corporate "Call to Action: Investing in Women's Right to Health" to give more attention to the WEPs' health principle..$^{214}$

These initiatives from outside the human rights framework indicate a growing consensus outside the rights world that businesses should not only respect a comprehensive vision of the right to health for their workersincluding women and migrant workers-but also assume an active role, if not responsibility, for actualizing this vision. They underscore that the division between occupational health and general health no longer has a clear rationale and may do harm.

Under international human rights and labor law, women workers in global supply chains already have a right to health as human beings and to occupational health as workers. When economic, legal, cultural, social, or structural, restrictions in the workplace prevent women workers from exercising their health rights or enjoying reproductive autonomy, "they face inequalities in their health outcomes and in many other aspects of their lives." 215 Requirements regarding how States should operationalize the right to health, or the AAAQ Framework, could inform how corporate actors in global supply chains provide healthcare in their workplaces and better meet the needs of the changing labor force. At a minimum, States that have ratified certain international conventions must not impede access to health care and services on a discriminatory basis. States must also ensure that health care services, goods, and facilities are not only accessible, but also affordable, of quality, and culturally and linguistically appropriate. ${ }^{216}$ The evolution of health rights over the last sixty years was accompanied by increasing protections for gender equality. Health rights, including those pertaining to occupational safety, need to be better aligned to best protect the health and well-being of women workers. To that end,

\footnotetext{
212. CAlvert InVESTMENTS, CALVERT WOMEN's PRINCIPLES: 10TH ANNIVERSARy REPORT: PAST, PRESENT, AND FUTURE (2014), http://www.calvert.com/NRC/Literature/Documents/BR10089.pdf.

213. Overview, WOMEN'S EMPOWERMENT PRINCIPLES. http://weprinciples.org/Site/PrincipleOverview/ (last visited on February 1, 2016).

214. UN WOMEN \& UN GLOBAL COMPACT, CALL TO ACTION: INVESTING IN WOMEN's Right TO HEALTH, (2015), http://weprinciples.org/files/attachments/WEPs_Call_to_Action_Investing_in_Women's_Health.pdf.

215. Center FOR ReProductive Rights, Substantive EQuality AND ReProductive Rights: A BRiefing Paper ON Aligning Development GoAls With Human Rights OBLIGATIONS (2014).

216. Id.
} 
companies would do well to take a more expansive view of their risks when assessing worker health rights violations in their operations.

IV.

The UN Guiding PRINCIPLES, CoRporate Due Diligence \& WorkPlace

HEALTH

The UN Guiding Principles on Human Rights and Business represent the next stage in thinking about the responsibility of transnational corporations in human rights violations. The financial power of these business enterprises have expanded with the growth of the global economy in the second half of the twentieth century. ${ }^{217}$ The Guiding Principles provide an opportunity to reassess, particularly through the due diligence process, what the right to health means for women workers and what corporations can do to respect this right. To identify the responsibilities of business enterprises, the former U.N. Secretary-General and Nobel Laureate Kofi Annan appointed Harvard University Professor John Ruggie in 2005 as a Special Representative with the task of recommending a framework, based on substantial input from stakeholders around the world, for State and business compliance with human rights norms. ${ }^{218}$ In 2008, Ruggie issued the "Protect, Respect, and Remedy" Framework. Ruggie later introduced the Guiding Principles on Business and Human Rights to provide instructions on how to implement the framework. The Guiding Principles were subsequently unanimously endorsed by the Human Rights Council in 2011. ${ }^{219}$

The Guiding Principles rest on three pillars. The first is the State's duty to protect against human rights violations by businesses and other third parties. ${ }^{220}$ The second is the business responsibility to respect those rights by preventing, mitigating, and remedying human rights violations resulting from business activities. ${ }^{221}$ The third is that victims of human rights abuse should have access to judicial and non-judicial remedies.222

Under the Guiding Principles, international businesses now have an independent duty to respect human rights that exists regardless of "States" abilities and/or willingness to fulfil their own human rights obligations." 223 The language is best understood to mean that if a company is operating in a country where gender equality, for instance, is not upheld, the company still must adhere to this right. The Guiding Principles direct businesses to respect all human rights. These rights include, at a minimum, those recognized in the International Bill of Human Rights, which includes the ICCPR and ICESCR, and the

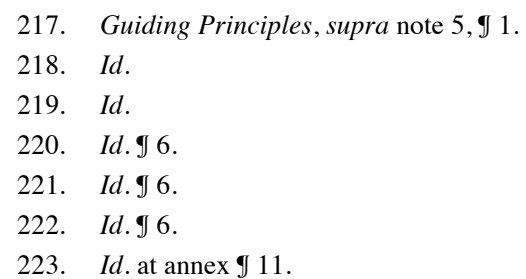


principles found in the ILO's Declaration on Fundamental Principles and Rights at Work. ${ }^{224}$ The corporate duty to respect is not merely a passive responsibility to comply with domestic laws and regulations, but rather it requires businesses to proactively take steps to avoid infringing human rights and address adverse human rights impacts that result from their business activities. ${ }^{225}$ This includes addressing impacts when they occur and finding ways to prevent or ameliorate human rights impacts directly connected to an enterprise's operations, products, or services, including abuses caused by an enterprise's business relationships even if they have not contributed to an abuse. ${ }^{226}$ This duty applies to all enterprises regardless of size, sector, ownership, structure, and the context in which they are operating. Instead, how they meet this responsibility will depend on these factors and the scale of an enterprise's "adverse human rights impacts." 227 In addition, when businesses have identified that they have caused or contributed to "adverse human rights impacts," they should actively engage in remediation by themselves or in cooperation with others. ${ }^{228}$

According to the Guiding Principles, the business duty to respect includes conducting human rights due diligence in order to better ensure that a business enterprise is able to avoid complicity in rights abuses. ${ }^{229}$ To satisfy the responsibility to respect, companies must: adopt a human rights policy statement at the most senior level of operations; conduct human rights impact assessments; integrate human rights policies throughout all divisions and at all levels of personnel; and track human rights impact and performance, including providing a confidential means for employees to report noncompliance. ${ }^{230}$ The due diligence process helps companies avoid engaging in abuses by assessing actual and potential human rights impacts, incorporating and acting upon the findings of these assessments; tracking their implementation; and communicating how they are addressing human rights impacts. ${ }^{231}$ The enterprise must examine the environment of the State in which the business operates, identifying specific human rights challenges unique to the location..$^{232}$ The business should determine whether any of its activity, in context, impacts human rights. ${ }^{233}$ Additionally, the business should also determine if its relationships with third

\footnotetext{
224. Id. at annex 12.

225. Id. at annex 11 .

226. Id. at annex $\mathbf{I} 13$.

227. Id. at annex 14.

228. Id. at annex $\mathbf{I} 22$.

229. Id. at annex 117.

230. John Ruggie, Special Rep. of the Secretary-General on the issue of human rights and transnational corporations and other business enterprises, Protect, Respect, and Remedy: a Framework for Business and Human Rights, IJ 60-63, U.N. Doc. A/HRC/8/5 (Apr. 7, 2008) [hereinafter Protect, Respect, and Remedy].

231. Guiding Principles, supra note 5, at annex I 17. For more discussion on how enterprises should engage in the due diligence process, see annex 9 18-21.

232. Protect, Respect, and Remedy, supra note 230, 57.

233. Id.
} 
parties, such as vendors or suppliers, impact human rights. ${ }^{234}$ The due diligence process should be an ongoing commitment by the enterprise to respect human rights. ${ }^{235}$ In regards to complicity, the Guiding Principles strongly emphasize that companies can avoid complicity by employing the due diligence processes which apply to their own activities and to their business relationships. ${ }^{236}$

The Guiding Principles do not create or reinterpret rights law; they describe only the corporate responsibility to respect human rights and the due diligence and other processes used to meet this responsibility. Gender experts have argued that the Guiding Principles need to address gender directly. ${ }^{237}$ Under direction from the Human Rights Council, Ruggie held an expert consultation in 2009 on how he could incorporate a gender perspective into the framework. ${ }^{238}$ The Guiding Principles in their final form refer explicitly to gender. The Guiding Principles highlight that States should provide guidance to business enterprises on how to effectively consider issues of gender and the specific obstacles that women and migrant workers and their families face. States must also ensure their efforts address the possibility of business involvement in human rights abuses, including sexual and gender based violence, during times of conflict. Also, the Guiding Principles ask that business enterprises recognize the different risks to women and men by having companies collect gender-disaggregated data in their tracking efforts to determine whether they are effectively mitigating and preventing human rights impacts. ${ }^{239}$ Although an improvement, there is no

\footnotetext{
234. Guiding Principles, supra note 5, annex I 17(a).

235. Id. at annex I 17(c).

236. Id. at annex I 17(c).

237. See Bonita Meyersfeld, Business, human rights and gender: a legal approach to external
} and internal considerations, in HUMAN RIGHTS OBLIGATIONS OF BuSINESS 202 (Surya Deva \& David Bilchitz eds., 2013) ("However, gender is not integrated throughout the GPs as a theme that recognises that generic principles may operate differently in practice for women and men. This position not only fails to reflect the reality that women are the majority of the population with specific group experiences but it is also out of sync with the rest of the UN system in developing specific principles regarding the eradication of gender specific harm throughout international human rights law."); see also Kathryn Dovey, Why Gender Matters for the Business and Human Rights Agenda in Southeast Asia, in Business AND HUMAN RIGHTS IN SOUTHEAST ASIA: RISK AND REgulatory Return 77 (Mahdev Mohan \& Cynthia Morel eds., 2015) ( "The UN Guiding Principles could have taken a stronger approach to gender issues and incorporated gender-sensitive language into various principles and commentary. . . the language incorporated into the final version is welcome and provides a foundation to build upon when considering the three pillars."); Andrea Shemberg, A Closer Look at the UNGPs, BEYOND GOOD BUSINESS, http://beyondgoodbusiness.org/andrea-shemberg-a-closer-look-at-the-ungps/ (last accessed on Mar. 2, 2016) (former legal advisor to John Ruggie stating the "UNGPs contain everything necessary to insure a gender-perspective implementation. The question is how that implementation is going to take place and how it's going to work in practice.").

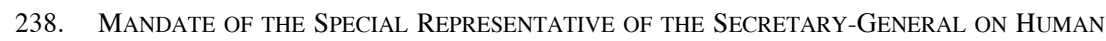
RIGHTS AND TRANSNATIONAL CORPORATIONS AND OTHER BUSINESS ENTERPRISES, INTEGRATING A Gender Perspective Into the UN "Protect, Respect, and Remedy" Framework (2009), https://business-humanrights.org/sites/default/files/reports-and-materials/Gender-meeting-forRuggie-29-Jun-2009.pdf.

239. That the Guiding Principles offer " $[\mathrm{g}]$ uidance to business enterprises on respecting human 
specific guidance on how gender should be included within the due diligence systems that corporate actors will need to implement.

Without more guidance to corporations on how to address gender considerations, it is likely that due diligence will not begin to consider the myriad ways corporate operations and their supply chains may be violating the health rights of women workers. Scholar Stephanie Barrientos, an expert on gender, global value chains, and decent work, has noted that codes of conduct designed around ILO conventions and national labor legislation may only cover a few gender issues related to formal employment, but not gender issues that cross between the personal and workplace domains. ${ }^{240}$

Although the concept of due diligence under the Guiding Principles has been criticized, ${ }^{241}$ due diligence is the essential entry point in bringing to light the health needs and possible violations women workers in global supply chains experience regarding their right to health, particularly their sexual and reproductive health. The due diligence requirements under the Guiding Principles require a defined gender approach if they are to serve the purposes they are intended to fulfill, namely to help corporations avoid complicity in violations of internationally recognized human rights, which include a strong foundation for the health and reproductive rights of women, whether employed or not, under existing legal and non-legal mechanisms. If the due diligence requirements in the Guiding Principles are thought of as a simple checklist for corporate actors that categorizes "health" as occupational health and safety, the violations of women workers' right to health in global supply chains will remain obscured. Moreover, if the due diligence requirements do not take into account the comprehensive nature of the right to health for women workers, State actors will continue to fail them in enforcing these rights.

rights should indicate expected outcomes and help share best practices. It should advise on appropriate methods, including human rights due diligence, and how to consider effectively issues of gender, vulnerability and/or marginalization, recognizing the specific challenges that may be faced by indigenous peoples, women, national or ethnic minorities, religious and linguistic minorities, children, persons with disabilities, and migrant workers and their families." Guiding Principles, supra note 5, at annex 3.

240. Barrientos, supra note 79, at 1517.

241. See Robert C. Blitt, Beyond Ruggie's Guiding Principles on Business and Human Rights: Charting an Embracive Approach to Corporate Human Rights Compliance, 48 TEX INT'L L. J. 33, 53 (2012) (describing the response of some civil society groups, such as Amnesty International, who criticized the Guiding Principles on several grounds, including failure to make due diligence a mandatory requirement); James Harrison, Establishing a meaningful human rights due diligence process for corporations: learning from experience of human rights impact assessment, 31 IMPACT ASSESSMENT \& PROJECT APPRAISAL 107, 108 (2013) (stating that the human rights due diligence requirement under the Guiding Principles must address additional requirements of transparency, external participation and verification, and independent monitoring and review); Olga MartinOrtega, Human Rights Due Diligence for Corporations: From Voluntary to Hard Law at Last? 32 NETH. Q. OF HUM. RTS. 44, 56 (2013) (commenting that the human rights due diligence requirement under the Guiding Principles goes beyond a corporate governance standard of risk management but, given the Guiding Principles' non-legal nature, does not impose consequences on corporate actors who do not conduct adequate due diligence). 
The Guiding Principles provide leverage to improve the health and wellbeing of women workers in global supply chains as they have been incorporated into other frameworks by other international agencies, such as the OECD Guidelines for Multinational Enterprises, ${ }^{242}$ the UN Global Compact, ${ }^{243}$ and the corporate performance standards of the International Finance Corporation. ${ }^{244}$ While the Guiding Principles are a recent development, a 2016 survey of 94 companies representing the largest firms in five sectors found that the most common actions taken in response were "the development of human rights policies, increased management capacity to address human rights issues and strengthened supply chain management." ${ }^{245}$ The survey also found that companies are increasingly conducting human rights impact assessments. For instance, Coca Cola has committed to undertaking 28 country assessments on land rights and child and forced labor of its sugar supply chain by $2020 .^{246}$

How health is addressed under the Guiding Principles can also influence the way a range of corporate accountability mechanisms - from fair trade to workplace monitoring, certification regimes, and social and environmental reporting - address workplace health.

\section{V. \\ BUSINESS BENEFITS, HEALTH RIGHTS \& RECOMMENDATIONS}

It is time for rights advocates, corporate actors, and other interested parties to engage in a robust discussion on what the right to health entails for women workers - and all workers - in global supply chains. As we have argued, a more expansive approach is justified not only by the changes to the global economy, the gender makeup of the workforce, and the real life experiences of women workers, but also by the evolving understanding of health rights under international law and the recognition of the unjustifiable and gender-biased segregation of worker rights as occupational health.

The first place to start is with the Guiding Principles as these provide a framework for corporate responsibility for human rights and require a due diligence process to assess risk. Due diligence is about asking the right

242. See ORG. FOR ECON. CO-OPERATION AND DEV. [OECD], OECD GUIDELINES FOR MULTINATIONAL ENTERPRISES (2011), http://dx.doi.org/10.1787/9789264115415-en/.

243. See The Ten Principles of the UN Global Compact, UNGLOBALCOMPACT.ORG, https://www.unglobalcompact.org/what-is-gc/mission/principles/principle-1 (last visited November $6,2016)$.

244. INT'L Fin. CORP., UN GUIDING PRINCIPLES ON BUSINESS AND HUMAN RIGHTS AND IFC

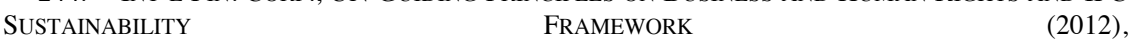
http://www.ifc.org/wps/wcm/connect/topics_ext_content/ifc_external_corporate_site/ifc+sustainabili ty/learning+and+adapting/knowledge+products/publications/un_guidingprinciplesbusinesshumanrig hts.

245. Bus. \& Human Rights Res. Ctr., ACTION ON Business AND HuMAN Rights: WhERE ARE WE NOW? 6 (2016).

246. Id. 
questions. If due diligence under the Guiding Principles conforms only to a narrow occupational safety and health lens, then corporate risk assessments will not ask the kinds of questions that will identify potential violations of women workers' rights to access quality services-including reproductive health-and health education and information. The Human Rights Commission and supporting actors should develop corporate guidance, incorporating a needed gender perspective, on how to assess the full range of health rights. Any assessment that takes a thorough look at health rights should use the Availability, Accessibility, Acceptability and Quality (AAAQ) framework as the basis for its investigation. Workplaces that are aligned with the AAAQ framework for their health facilities will not only meet their legal obligations but also improve worker health by going beyond occupational safety needs. As Professor Lawrence O. Gostin, Director of the World Health Organization's Collaborating Center on Public Health Law and Human Rights, points out, when human rights are incorporated in policy-making processes, health facilities can provide services that are nondiscriminatory and of good quality. ${ }^{247}$ The use of the AAAQ Framework in these workplace health facilities can ensure that services are informed by and centered around the needs of workers.

Second, organizations and corporations that manage or promote what might be called soft, non-legal, regulatory mechanisms under corporate social responsibility can also provide leadership for advancing a more expansive notion of health rights at the workplace-and provide corporations testing grounds to learn what works and how best to achieve results. Nothing prevents corporate social responsibility-focused organizations from advancing a progressive agenda that recognizes the shortcomings to date in addressing gender equality as it relates to worker health. As is often noted, corporate social responsibility and other voluntary private-public partnerships cannot displace corporate obligations under the Guiding Principles ${ }^{248}$ nor legal obligations corporate actors have within the jurisdictions where they are operating. However, corporate social responsibility efforts may build the capacity of local and national governments not only to meet national labor standards, but also to meet international human rights and labor laws and norms. ${ }^{249}$ This is particularly true in regards to gender equality where national laws may still be retrogressive or maintain the status quo. In addition, corporate social responsibility efforts in regards to the right to health may further develop the infrastructure, resources,

\footnotetext{
247. See Lawrence O. Gostin, Global Health Law (2014).

248. See generally Guiding Principles, supra note 5.

249. For instance, the rights in the ICESCR must be progressively realized by states, meaning that states must take steps to achieve these rights within a short time after the ICESCR has gained legal force for a specific state party, and states owe a minimum core of obligations that satisfy the minimum essential levels of each right. CESR illustrates this duty with the following: a state that has a significant number of persons deprived of foodstuffs, essential primary care, basic shelter or housing, or basic forms of education would be failing to discharge obligations under ICESCR. See ICESCR, supra note 105, at Art. 2(1) General Comment 3 I 10.
} 
and provider pools needed for States to ensure that healthcare is accessible, available, acceptable, and high quality.

Third, national governments and organizations involved in health policy at the country level can review public health and occupational health policy and regulations to see where these can be aligned. This review needs to consider not only what additional standards and practices should be asked of industry, but also how government resources for public health improvements can help protect worker health rights. For instance, public agencies in partnership with companies can make sure workplace nurses are fully linked into registration, licensing, and professional development programs and requirements, and ideally can develop a continuing medical education program to improve the skills of nurses to practice effectively in the workplace setting.

Unlike many rights issues, which can be contentious, addressing the health of women and men workers is not only important for the health and well-being of workers, but also benefits corporations and their suppliers' companies in ways that are currently yet to be realized. The goal of a more expansive approach to OSH standards is to ensure the health rights of women workers are respected and protected, not to turn workplaces into public health facilities. There is much evidence from high income as well as low and middle-income countries that shows businesses benefit from improved worker health. ${ }^{250}$ Workers are more productive and focused, have fewer injuries, and have higher morale. ${ }^{251}$ Workplaces with a focus on women's health have lower absenteeism and turnover. ${ }^{252}$ In fact, health is correlated with positive economic growth due to the increased participation of women in the workforce. ${ }^{253}$ Additionally, a narrower gender gap is associated with increased competitiveness and development.

The business case for better conduct must also recognize the fact that many supplier companies are already paying for infirmaries and health care staff on site, but are getting little actual return from their investment ${ }^{254}$ as the staff could be providing more and better services. ${ }^{255}$ Since most workplace managers see these resources as required costs necessary to meet compliance, they do not recognize that the infirmary and health staff can be strategic resources that

250. See Langer et al., supra note 2, at 19.

251. See Ron Goetzel, Common Themes Underpinning Workplace Health Promotion Programs, NAT'L ACAD. (Dec. 2015), http://iom.nationalacademies.org/ /media/Files/Activity\%20Files/Global/PublicPrivatePartnerships/ Shared\%20Value\%20Dec\%202015/Presentations/Goetzel\%20Final.pdf; see also Larry S. Chapman, Meta-Evaluation of Worksite Health Promotion Economic Return Studies: 2012 Update, The Art of Health Promotion Newsletter, J. OF HeAlth PROMOtion, Mar.-Apr. 2012.

252. RACHEL YeAgER, THE BUSINESS RETURNS FROM WOMEN's HEALTH PROGRAMS 9 (2011).

253. David E. Bloom et al., The Effect of Health on Economic Growth: Theory and Evidence. NAT'L BUREAU OF ECON. RES, 20 (Nov. 2001), http://www.nber.org/papers/w8587/.

254. BSR, supra note 36 , at 9.

255. Id. 
improve worker well-being, management relations, and productivity. Thus, focusing on health rights under the AAAQ framework and other measures is also a way to get a return on investment from money they have already spent. In this case, asking to focus on women's overall health rights is also asking managers to think like the business-people they already are. An active, trained, and supported nurse is able to promote healthy behaviors at work and at home, educate workers on important health issues, and ensure they get quality care at the workplace and in the community.

Finally, many transnational corporations have made public commitments to supporting the Sustainable Development Goals, women's empowerment, and gender equality. Corporations need to make explicit commitments to include the women's health component of the SDG's relating to their own operations. Providing onsite reproductive health services or medical coverage that includes these services impact maternal and newborn deaths that affect a State's economy. For instance, between 30-50\% of Asia's economic growth from 1965 to 1990 was attributed to reproductive health improvements and the reduced rate of both fertility and infant and child mortality. ${ }^{256}$ Furthermore, $30 \%$ of Britain's GDP growth is attributable to improvements in health and nutrition between 1780 and 1979, and $11 \%$ of low- and middle-income countries' economic growth is related to reduced adult mortality between 1970 and $2000 .^{257}$ The Lancet Commission describes this effect as a virtuous circle: "health contributes to economic growth and wellbeing, which results in improved health and leads to increased resources for better, widespread health care. Women's contributions to health care have a multiplier effect because health is an investment that drives productivity and economic and human development at individual and national levels. Healthy children are able to learn and become productive." 258

VI.

\section{CONCLUSION}

In 2002, shortly after Paul Hunt was named as the first UN Special Rapporteur on the right to health, he presented his vision for promoting the right to health as a fundamental human right, clarifying the content of this right and identifying good practices at the community, national, and international levels. ${ }^{259}$ He wrote:

Effectively promoting the right to health requires identifying and analyzing the complex ways in which discrimination and stigma have an impact on the enjoyment of the right to health of those affected, particularly women, children, and marginalized groups... Promoting the right to health also requires gathering and analyzing data to better understand how various forms of discrimination are

256. Bloom et al., supra note 253.

257. See UN WOMEN \& UN GLOBAL COMPACT, supra note 214, at 2.

258. Langer et al., supra note 2, at 19.

259. Id.; see also Paul Hunt, The UN Special Rapporteur on the Right to Health: Key Objectives, Themes, and Interventions, 7 HEALTH AND HUM. RIGHTS (2002). 
determinants of health, recognizing the compounding effects of multiple forms of discrimination, and documenting how discrimination and intolerance affect health and access to health care services. ${ }^{260}$

His vision remains true today for women's health at the workplace in global supply chains. In an era where women and families must often migrate to find work, leaving behind their homes and support networks, the workplace can be a site where they can access resources and information to actualize their right to health. But in global supply chains, the workplace becomes a place that frequently puts up barriers to their right to health, if not direct violations. For women workers in these labor markets the violations to their right to health remain unrecognized due to the narrow focus on occupational safety and health violations by advocates, corporations, and others. Moreover, gender inequality and gendered biases within global supply chains and the legal frameworks meant to protect these workers exclude women's experiences and ignore how the workplace impacts the personal lives of women workers.

The Guiding Principles could be used to explore how corporations can respect an expansive vision of the right to health for women workers in global supply chains given its charge for corporations to respect, at a minimum, the International Bill of Human Rights and the ILO's Declaration on Fundamental Principles and Rights at Work. ${ }^{261}$ As discussed above, the right to health is part of the International Bill of Human Rights and includes not only occupational health and safety, but also sexual and reproductive health and protections for pregnant workers and external migrants. ${ }^{262}$ In addition, non-legal declarations are calling for corporate actors to look beyond their occupational health and safety obligations and see how their workplaces can help actualize a comprehensive vision of health for their workers. The due diligence requirements in the Guiding Principles must include a gender lens and incorporate the comprehensiveness of the right to health as explained in multiple human rights and labor conventions. If the due diligence requirements in the Guiding Principles are approached as a simple checklist that categorizes "health" as solely occupational health and safety, the rights and violations of women workers in global supply chains will remain obscured. Moreover, little will improve if due diligence does not take into account the comprehensive nature of the right to health including the AAAQ framework as articulated in international instruments.

Businesses can be agents for change for the right to health of women workers by leveraging their resources and relationships with governments to collaborate in creating and implementing policies, infrastructure, and programs that ensure the right to health for workers and their communities. Such a "winwin" proposition will require a change of perspective. Recognizing the

260. Id. at 9 .

261. Declaration on Fundamental Principles, supra note 69.

262. See discussion infra Part A 
importance of aligning occupational safety and rights-based approaches can do much to advance the well-being of women workers around the world. 